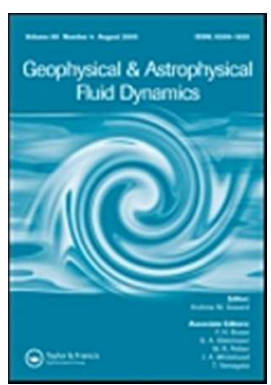

\title{
Shelf-Basin Exchange in the Laptev Sea in the Warming Climate: a model study
}

\begin{tabular}{|r|l|}
\hline Journal: & Geophysical \& Astrophysical Fluid Dynamics \\
\hline Manuscript ID: & GGAF-2014-0012.R1 \\
\hline Manuscript Type: & The dynamics of shelf seas Special Issue \\
\hline Complete List of Authors: & $\begin{array}{l}\text { Ivanov, Vladimir; Arctic and Antarctic Research Institute, } \\
\text { Maslov, Pavel; OOO "Eco-Express-Service", } \\
\text { Aksenov, Yevgeny; National Oceanography Center, } \\
\text { Coward, Andrew; National Oceanography Center, }\end{array}$ \\
\hline Keywords: & $\begin{array}{l}\text { shelf-basin exchange, dense water cascading, Arctic ocean, sea ice, } \\
\text { climate change }\end{array}$ \\
\hline
\end{tabular}




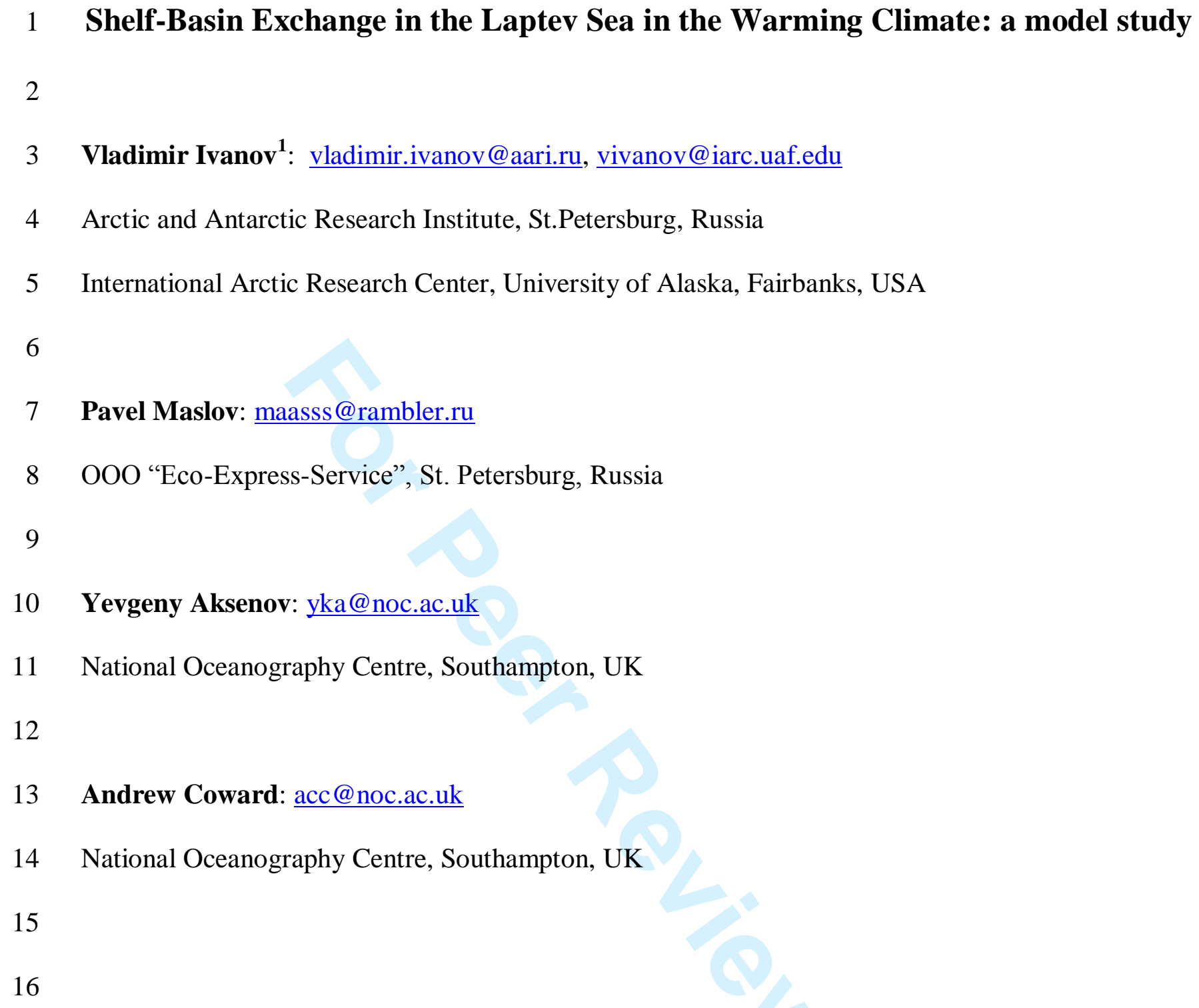

\footnotetext{
${ }^{1}$ Corresponding author
} 
19 Abstract. GCM-based forecast simulations predict continuously increasing seasonality of the sea 20 ice cover and an almost ice-free, summer-time, Arctic Ocean within several decades from the 21 present. In this study we use a primitive equation ocean model: NEMO, coupled with the sea ice model LIM2 to test the hypothesis that under such increased range in seasonal ice cover the intensity of shelf-basin water exchange will significantly increase. We use the simulated results for

the Laptev Sea from a global model run 1958-2007 and compare results for two years with anomalously high/low summer sea ice extent: 1986-1987 and 2006-2007. The shelf-basin fluxes of volume, heat and salt during specific seasons are evaluated and attributed to plausible driving processes, with particular attention to dense water cascading. Analyses of the model temperature distribution at the depth of the intermediate maximum, associated with Atlantic Water, have demonstrated marked increase of the amount of the local origin cold water in late winter 2007 in the region, where dense water typically appears as a result of its formation on the shelf and subsequent downslope leakage. Calculation of the shelf-basin exchange during March-May in both years confirmed a substantial increase of fluxes in 'ice-free' 2007 compared to the 'icy' 1987, on the average by 2 times. According to several past model studies, dense water production on Arctic shelves in winter driven by ice freezing and salt ejection is not likely to cease in a warmer climate, but rather the opposite. There is also observational evidence that cascading in the seasonally ice covered seas (e.g. the Barents Sea) is much more efficient than it is in the permanently ice covered Arctic Ocean, which supports the presented model results. ice extent, the winter one has not radically changed over these years. This seasonal dissimilarity eventually led to dominance of the first-year ice over the multiyear ice. Between 2004 and 2008 the 
46 area of the first-year ice exceeded the area of the multiyear ice by about a factor of two (Kwok et al. 47 2009). GCM-based simulations predict continuously increasing seasonality of the sea ice cover and 48 almost ice-free Arctic Ocean in summer within several decades from the present. (CMIP5, 49 http://pcmdi3.llnl.gov/esgcet).

What consequences for the other components of the Arctic environment could we expect if such scenario becomes reality? A retreating summer ice edge increases the size of the marginal ice zones (MIZ) - the transient area between the open water and ice-covered ocean. Rapid changes in the state of the ocean surface over the limited distance mean high horizontal gradients of properties in oceanic and atmospheric boundary layers below and above the MIZ. High gradients trigger strong motions in both strata, providing favorable prerequisite conditions for intensive horizontal and vertical exchange of properties. In a general sense, decreasing ice cover is shifting the energy balance at the sea-air interface to a higher level, which is characterized by intensified fluxes of momentum, heat and moisture. In several past studies it has been shown that the retreat of the summer ice edge in the Arctic Ocean also enhances horizontal and vertical exchange of water across the shelf-break.

The efficiency of shelf-basin exchange in the areas neighboring the MIZ is strongly controlled by the location of the ice edge relative to the bottom topography. In summer season retreat of the ice edge seaward of the shelf-break favors wind-induced upwelling to deliver salty, nutrient-rich water from the deep on shelf (Carmack and Chapman 2003). Continuous retreat of the ice cover exposes waters off the shelf-break for longer periods of time, increases the intensity of upwelling, efficiency of mixing and shelf-basin exchange (Pickart et al 2009, Rainville et al, 2011). In winter season, when the Arctic Ocean is almost totally covered by ice, pockets of active shelfbasin water exchange are associated with latent-heat polynyas - extended openings in the ice cover, current (cascading). Shelf-slope cascading invokes compensatory ascending flow of the deep water 
73 Golovin 2007). Similar to upwelling, polynyas are generated by the favorable wind which breaks up

74 the fast ice and moves ice floes offshore (Pease 1987). Later onset of freezing, due to progressive

75 degradation of the summer ice cover, predisposes thinner ice during the next winter (Stroeve et al.

76 2011). Thinner ice is more mobile and fragile, thus being stronger affected by the wind stress.

77 Thence, we may anticipate that in the warming climate shrinking summer ice cover should facilitate 78 shelf-basin water exchange throughout the entire year.

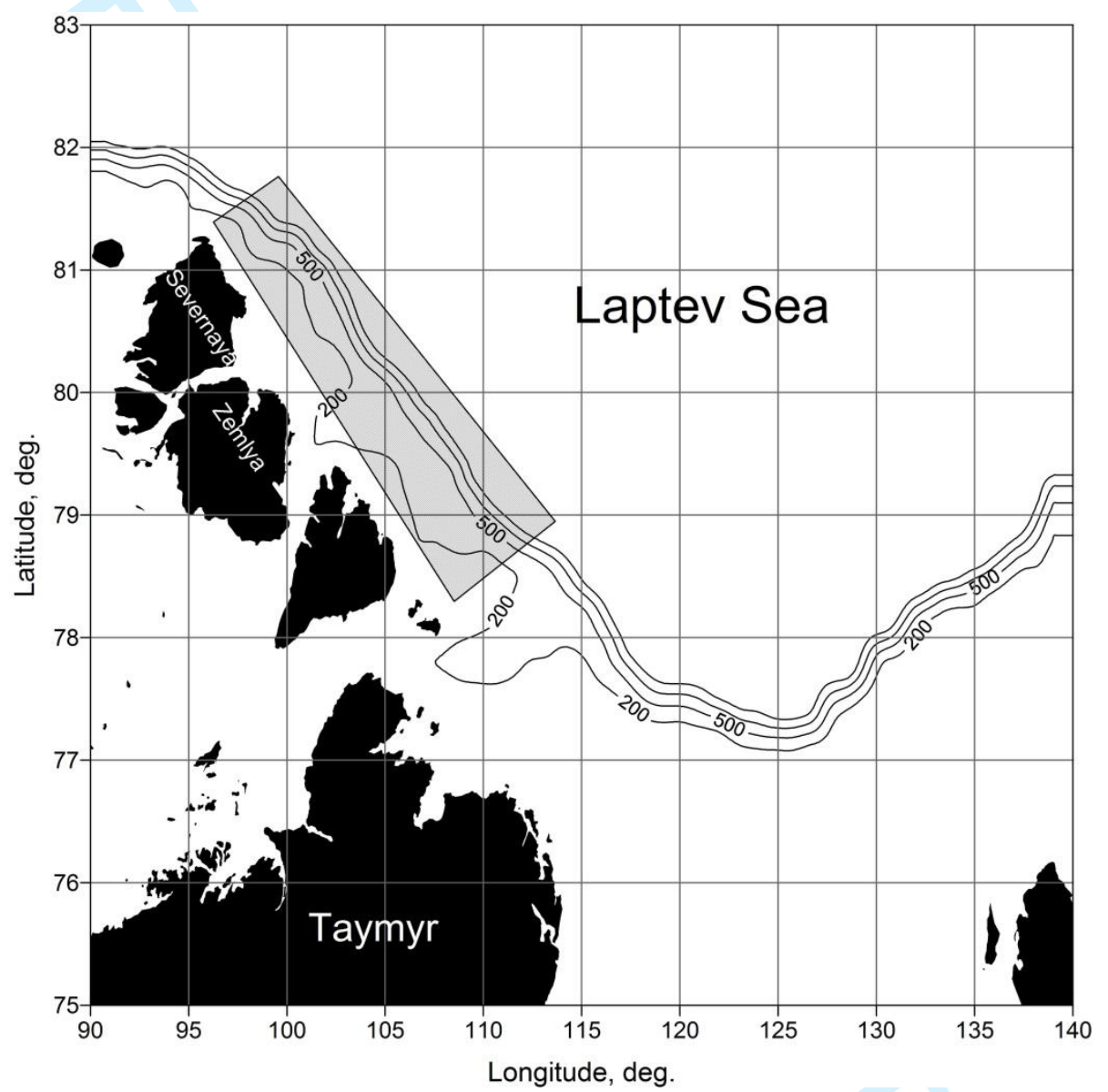

80 Figure1. The study area. Smoothed bottom topography of the shelf-slope is shown by solid lines. 81 Polygon marks the region, where flux calculations were performed.

In this study we use hindcast results from a primitive equation ocean model NEMO

(Madec et al. 1998), coupled with the sea ice model LIM2 (Fichefet and Maqueda 1997) to test this hypothesis in the Laptev Sea (Figure 1). The Laptev Sea plays very specific role in shaping the Arctic Ocean climate conditions. The major Arctic surface current - the Transpolar Drift, predominantly originates in the northern Laptev Sea and transports sea ice towards Fram Strait 8 (Wiese 1948, Nikiforov and Shpaikher 1980, Krumpen et al. 2013). Intensity of the Transpolar Drift 
89 is controlled by the prevailing atmospheric forcing - cyclonic/anticyclonic (Proshutinsky and

90 Johnson 1997). The type of atmospheric circulation also preconditions local hydrography by

91 changing the pathways of riverine waters (Dmitrenko et al. 2010a, Morison et al. 2012), and

92 facilitating/impeding shelf-slope exchange due to cascading/upwelling (Rudels et al. 2000,

Dmitrenko et al. 2010b). The Laptev Sea shelf is a prominent dense water formation site (Aagaard et al. 1981, Martin and Cavalieri 1989, Dethleff 2010). Cold dense water, which forms in winter polynyas on the north-western shelf, cascades into adjacent deep basin, modifying AW (Ivanov and Golovin 2007), which circulates cyclonically around the major Arctic basins (Rudels et al. 1994).

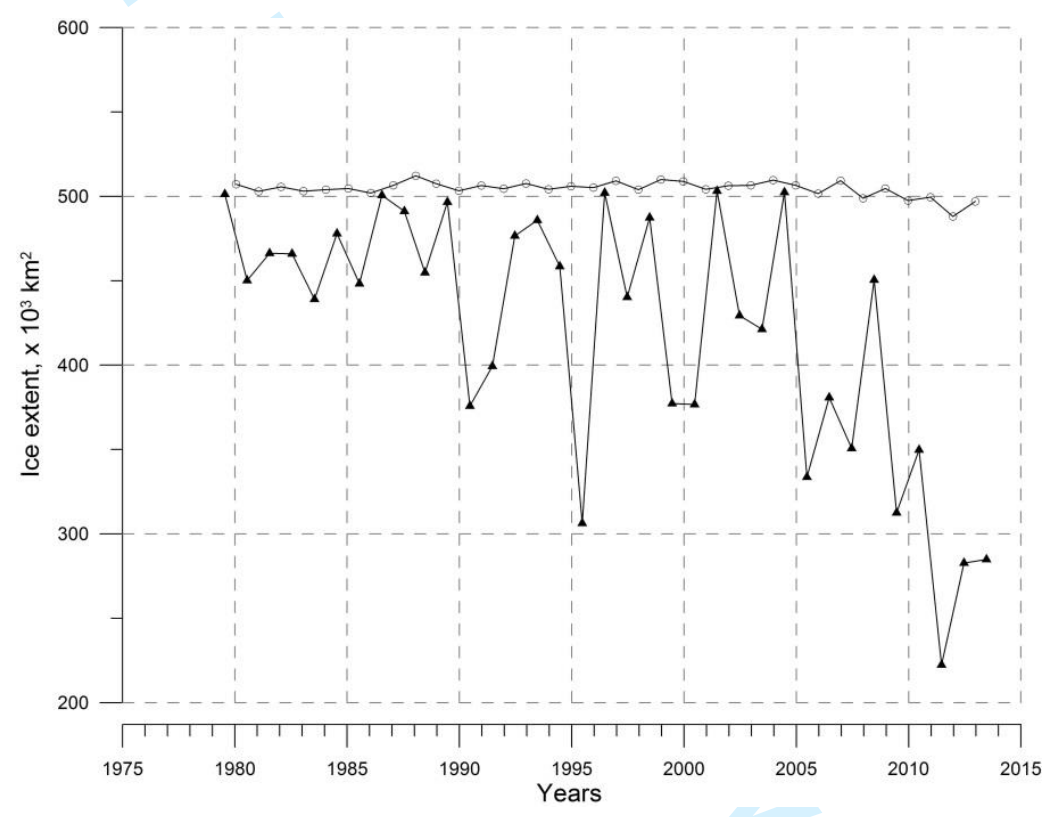

Figure 2. Time series of ice extent (15\% concentration) according to satellite data: open circles denote winter season (Dec - May), triangles denote summer season (Jun - Nov) (Cavalieri 1996, http://nsidc.org/data/nsidc-0051.html).

In 1990-2010s sea ice conditions in the Laptev Sea have undergone similar changes as those on the pan-Arctic scale. Seasonality of the ice cover substantially increased after 2005 (Figure 2), while the mean ice thickness had diminished (Frolov et al. 2009). This observed rapid transition provides an opportunity to test theoretical hypotheses on the effect of the sea ice state on shelf-slope exchange . The goal of this study is to quantify the range of possible effects produced by increasing seasonality of the sea ice cover on shelf-basin exchange in the Laptev Sea. To achieve this goal, we used results of the global NEMO-LIM2 model run 1958-2007. We post-processed and analyzed the 
yearly model output with respect to the Laptev Sea for two years with high/low summer ice extent: 1986-1987 and 2006-2007 (see Figure 2). The major target of the analysis was the evaluation of shelf-basin fluxes of volume, heat and salt during specific seasons and their attribution to plausible driving processes, with particular attention to dense water cascading.

The paper consists of 5 sections. In the second section we briefly describe the configuration of the global NEMO model used for this study. In Section 3 we present model results with respect to the Laptev Sea, and compare model output with available observations and satellite data. Calculation of fluxes and their comparative analysis for two selected years is carried out in Section 4. Discussion of obtained results and general conclusions finalize the paper.

\section{Methods}

\subsection{Global NEMO-LIM2 configuration}

The Nucleus for European Modelling of the Ocean (NEMO) is a state-of-the-art modeling framework for oceanographic research, operational oceanography seasonal forecast, and climate studies (http://www.nemo-ocean.eu/). The NEMO ocean model is a primitive equation model OPA9 (Madec et al. 1998) adapted to regional and global ocean circulation experiments. It is designed to be a flexible tool for studying the ocean and its interactions with other components of the earth climate system (in particular sea-ice) over a wide range of space and time scales.

Prognostic variables are the three-dimensional velocity field, a linear or nonlinear sea surface height, temperature, and salinity. In the horizontal direction, the model uses a curvilinear orthogonal grid and in the vertical direction, a full- or partial-step z-coordinate, or s-coordinate, or a mixture of the two. For the present study the model is configured on a common tri-polar Arakawa C-grid with the poles placed at the geographical South Pole, in Siberia and in the Canadian tundra. The grid has a horizontal resolution of 6-12 km in the Arctic Ocean admitting larger ocean eddies. There are 75 vertical levels (1-41 m thick in the upper $400 \mathrm{~m}$, increasing to $204 \mathrm{~m}$ thick at $6000 \mathrm{~m}$ ). For these simulations (1958-2007), the model was driven by the Common Ocean-Ice Reference Experiments (CORE2) dataset. The ocean model is coupled to the Louvain-la-Neuve sea ice model LIM2 


\subsection{Calculation of fluxes}

Generally, the significance of a specific physical processes to the maintenance of the given climate state of the system (ocean, atmosphere etc.) is assessed by some measurable parameters, which may characterize the overall (bulk) intensity of the considered process. The bulk components of the climatic structure of the ocean are water masses - large bodies of water with nearly similar temperature and salinity characteristics (Encyclopaedia Britannica 2014). Changes of temperature/salinity within water masses are caused by horizontal and vertical fluxes of heat/salt across their boundaries. Hence, the magnitude of heat/salt fluxes between water masses, associated with the studied process may serve as a measure of the efficiency of this process in changing the given state of the ocean. In this study we were interested in changes of shelf-basin water exchange in the Laptev Sea, which may be quantitatively characterized by changes in corresponding heat/salt fluxes.

At the post-processing stage model results were used for calculating volume/heat/salt fluxes $\left(F_{k}\right)$ according to the algorithm introduced in (Ivanov and Golovin 2007):

$$
F_{k}\left(x_{1}, x_{2}, z_{1}, z_{2}, t\right)=\frac{1}{\left(x_{2}-x_{1}\right)\left(z_{2}-z_{1}\right)} \int_{x_{1}}^{x_{2}} d x \int_{z_{1}}^{z_{2}} \Delta K \cdot v_{n} d z
$$


161 where $K\left(1, \rho c_{P} T, \rho S\right)$ is 'vector' with components, describing water volume, heat, and salt content; $162 \Delta K$ is the horizontal contrast between shelf and the deep water; $v_{n}$ is the velocity component normal 163 to bottom topography and directed offshore; $d x$ is the unit distance along the topography contour 9

\section{Modelled sea ice, thermohaline properties and currents}

A detailed analysis of the NEMO model results with respect to the Arctic Ocean

thermohaline structure, ocean dynamics, exchanges through the Arctic straits and sea ice and their temporal variability can be found in (Jahn et al. 2012, Johnson et al 2012, Lique and Steele 2012, Jackson et al. 2014). Brief discussion of differences in the pan-Arctic circulation in September 1987 and 2007 is provided in the supplement file. In this section we focus on the results of simulation for the Laptev Sea around annual (September - September) for two studied years with substantially different ice conditions, shown in Figure 3 and 4. As follows from these figures, modelled monthly mean ice extent and ice concentration in the Laptev Sea reasonably coincides with the actual one, 
(a)

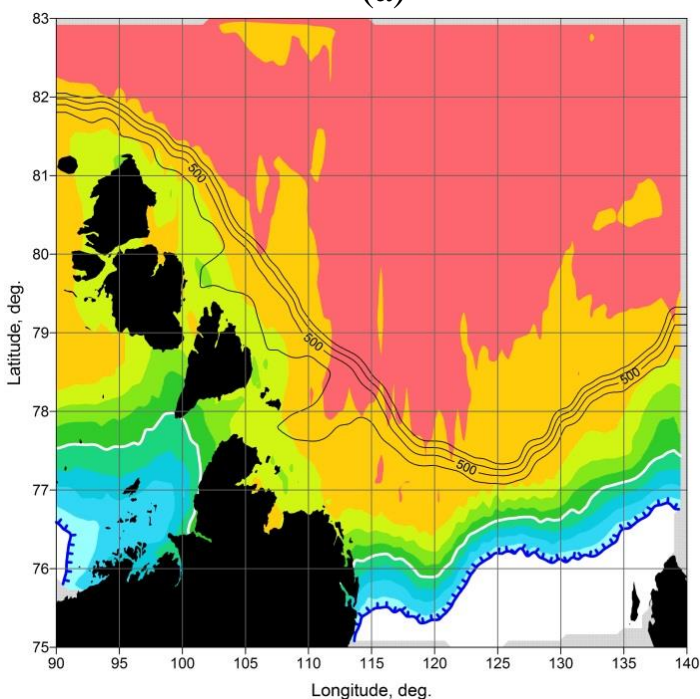

(b)

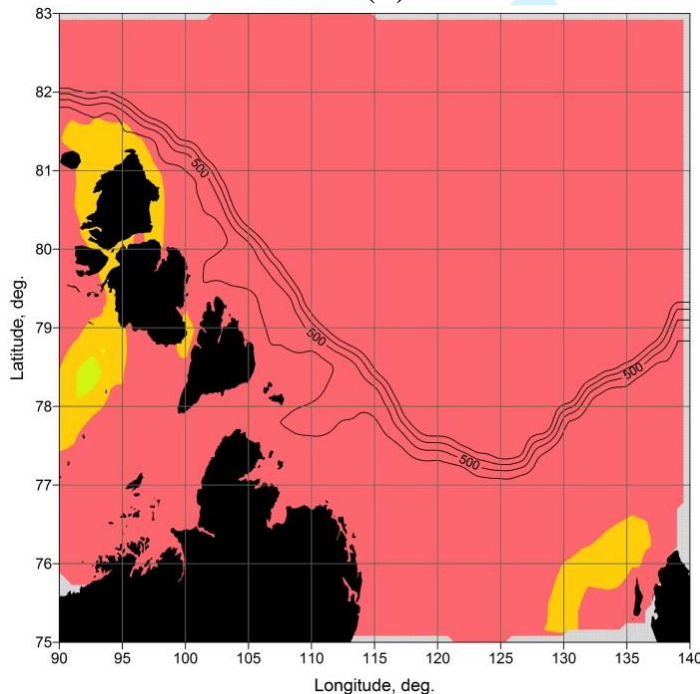

(c)

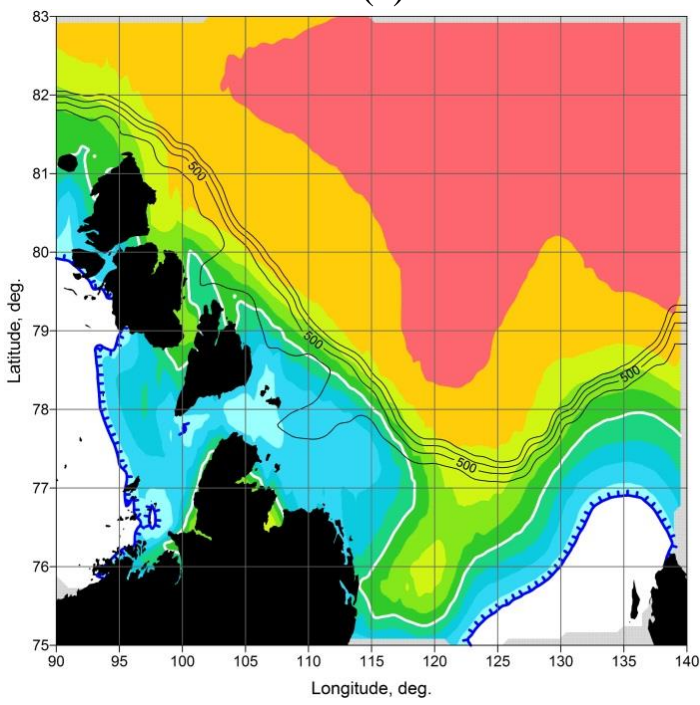

(d)

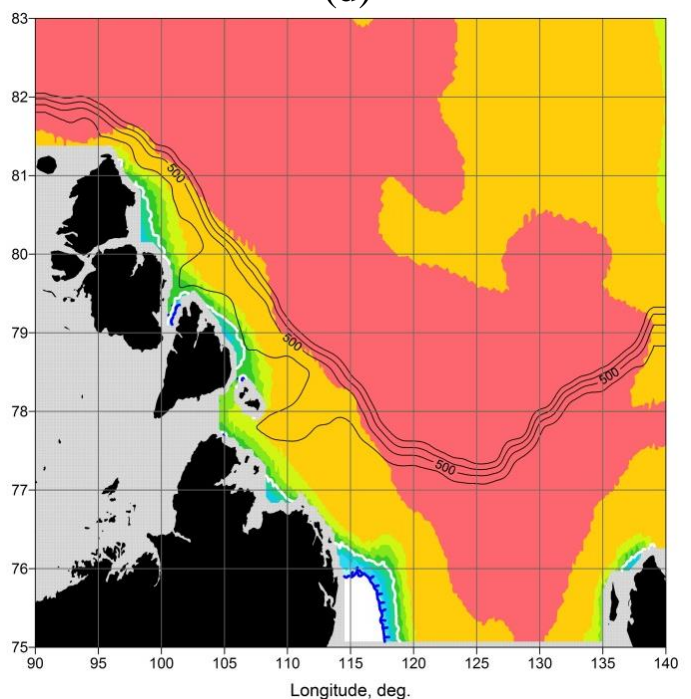

(e)

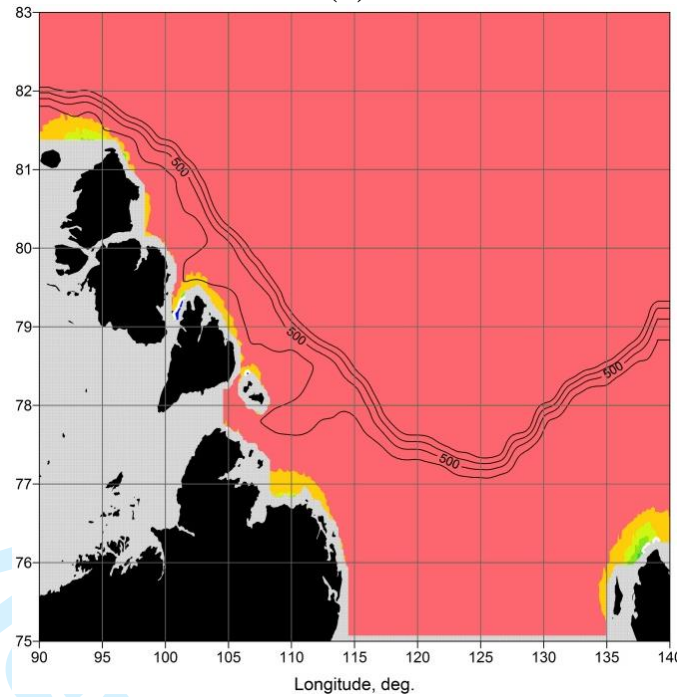

(f)

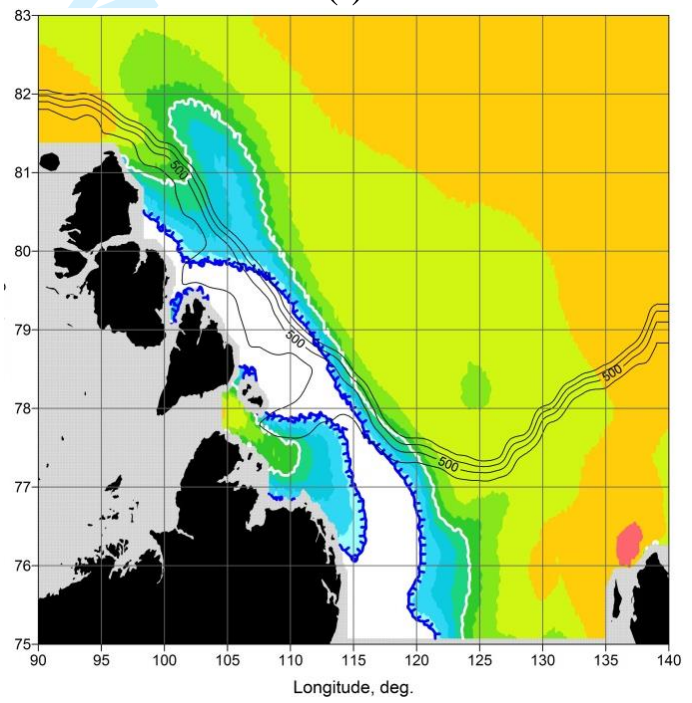

Figure 3. Mean monthly ice concentration in 1986-87: September-1986, April-1987, September1987 according to satellite data (a, b, c) and model calculations (d, e, f) respectively.

Although the exact patterns differ in specific regions, the average deviation of the model data from the actual total ice concentrations within the studied area over 1986-87 and 2006-2007 
190 does not exceed $14 \%$. This coincidence is generally better in $1986-1987$ and in winter time. The

191 largest deviation of the model from the actual ice concentration is observed in September 2007,

192 when model data underestimate actual ice retreat (Figure 4-c, f). It is important to draw attention to

(a)

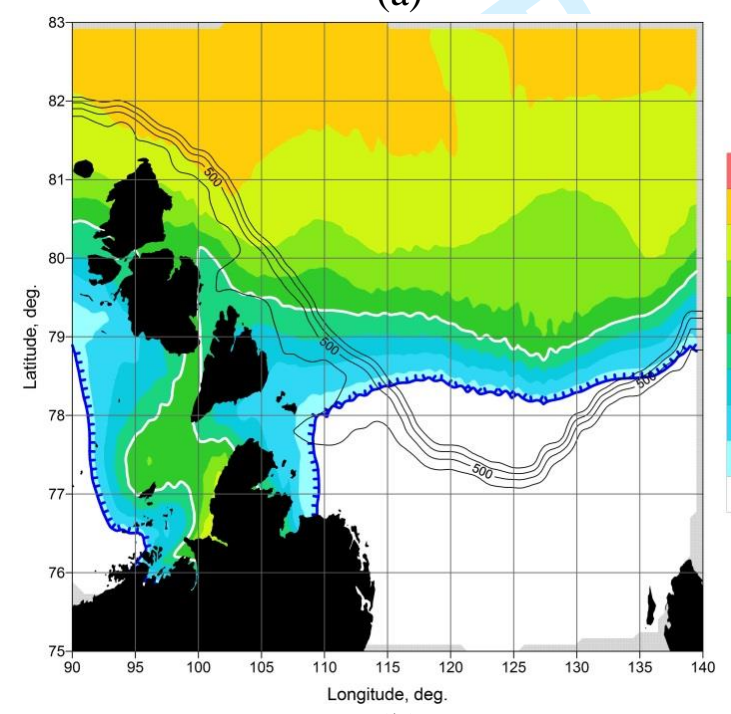

(b)

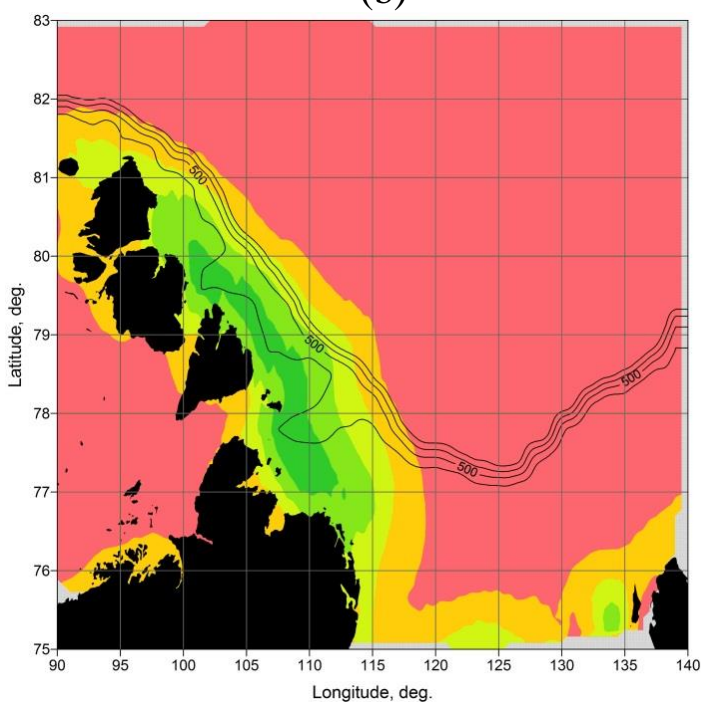

(c) (d)

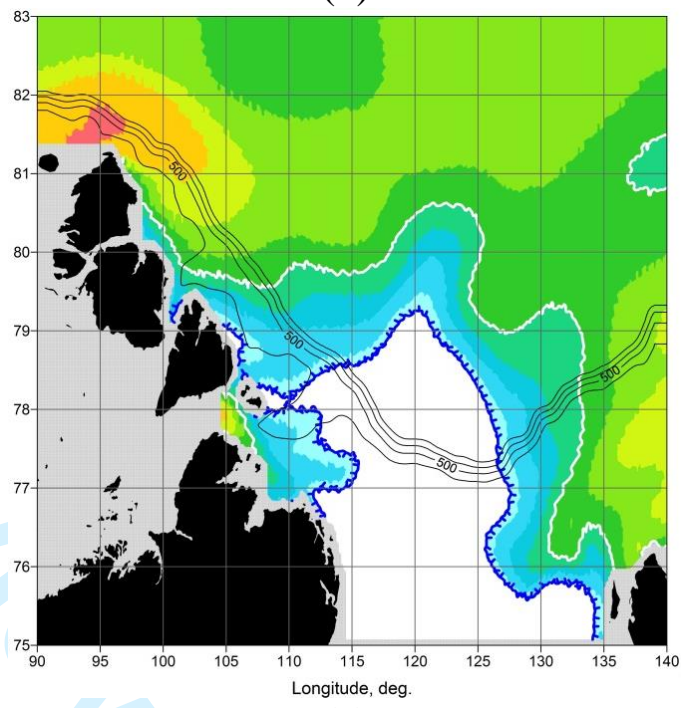

(e)

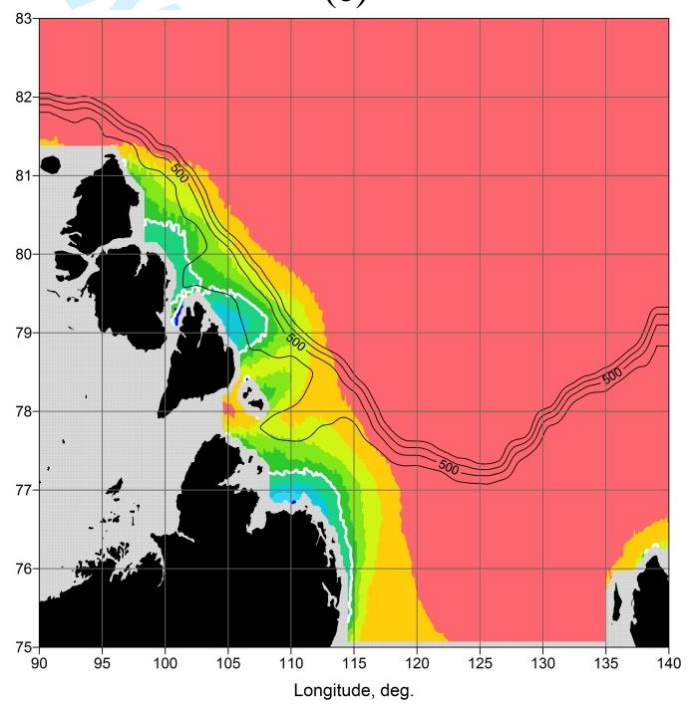

(f) 


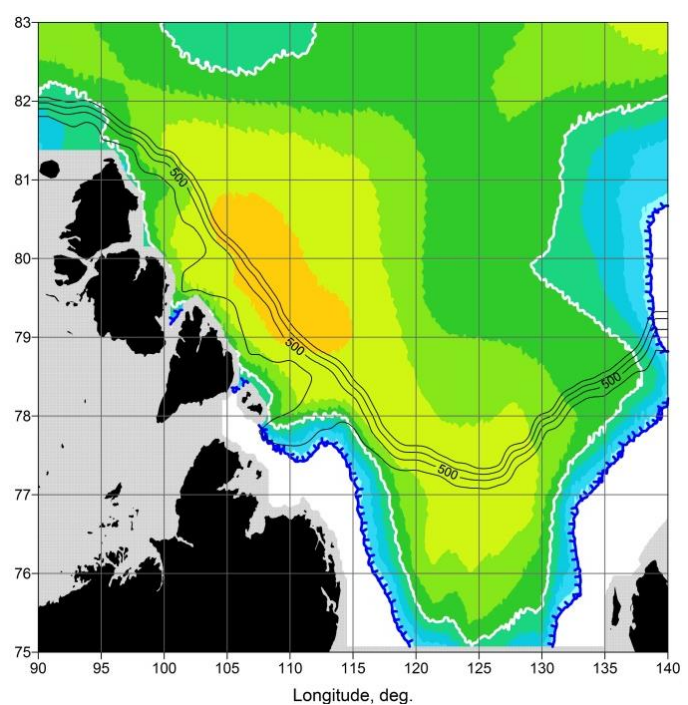

Figure 4. Mean monthly ice concentration in 2006-07: September-2006, April-2007, September2007 according to satellite data $(\mathrm{a}, \mathrm{b}, \mathrm{c})$ and model calculations (d, e, f) respectively.

Thermohaline conditions in the intermediate water layers of the Laptev Sea (from the depth of the outer shelf, about $100-120 \mathrm{~m}$ to $1000-1500 \mathrm{~m}$ over the continental slope) is controlled by three branches of Atlantic Water, Fram Strait Branch (FAW), Barents Sea Branch (BAW), shelf branch (SAW) and their interactions (Rudels 2013, Ivanov and Aksenov 2013). The existence of the SAW was predicted in the recent model study by (Aksenov et al. 2011) and is so far confirmed by indirect observational evidence. The major heat and salt influx into the Laptev Sea is provided by the FAW. The warm core of the FAW in the studied area is embedded at $230-270 \mathrm{~m}$ depth (EWG 1997, 1998). Therefore, we have focused on the $250 \mathrm{~m}$ depth to depict characteristic features of thermohaline and dynamical spatial structure, replicated by the model. As follows from Figure 5, general pattern of temperature and currents has not radically changed over the 20 years under review. FAW enters the studied area in the north-western corner and moves generally to the east, gradually losing heat due to horizontal and vertical mixing (Rudels 1994, Ivanov and Aksenov 2013). The strongest flow occurs in the narrow boundary current, which, according to the model retrospective, contains the SAW, originated in the north-eastern Barents Sea (Aksenov et al. 2011). FAW core is not associated with high current speed. There are several differences between Figure 5 (a) and (b). The most noticeable features are in the intensity of temperature maximum (higher) and temperature minimum (lower) in September 2007. Positive temperature shift in 2007 from 1986 is 
216 likely an indication of continuous AW warming in the Arctic Ocean after 1990 (Polyalov et al.

217 2005), captured by the model. Our explanation of the lower temperature minimum in September

2182007 is based on the hypothesis that a decisive contribution is made by dense water forming and

(a)

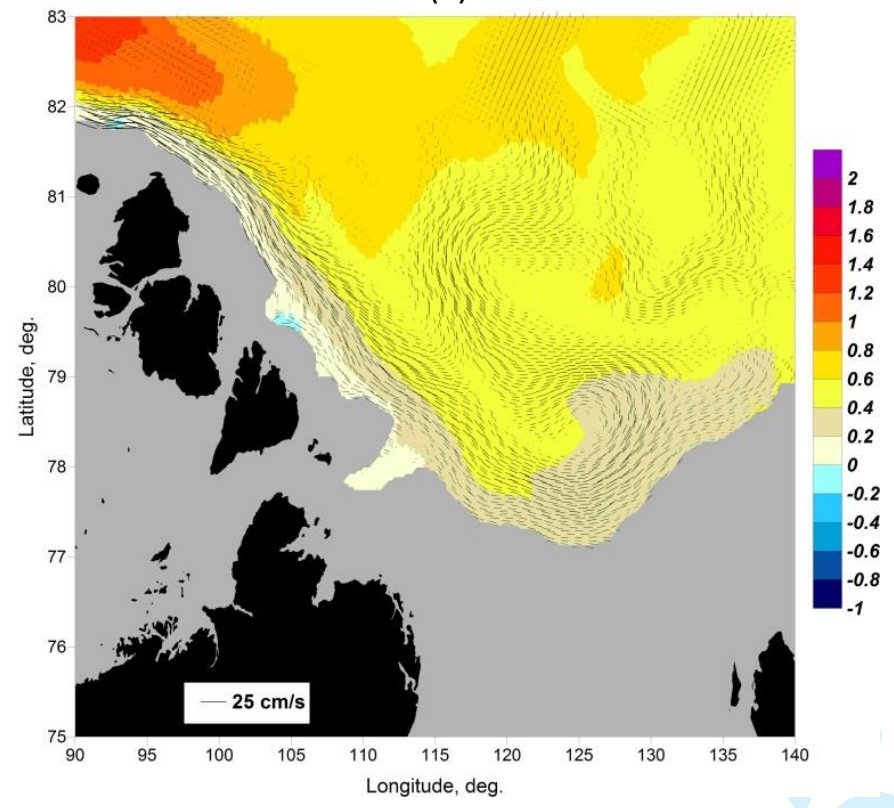

(b)

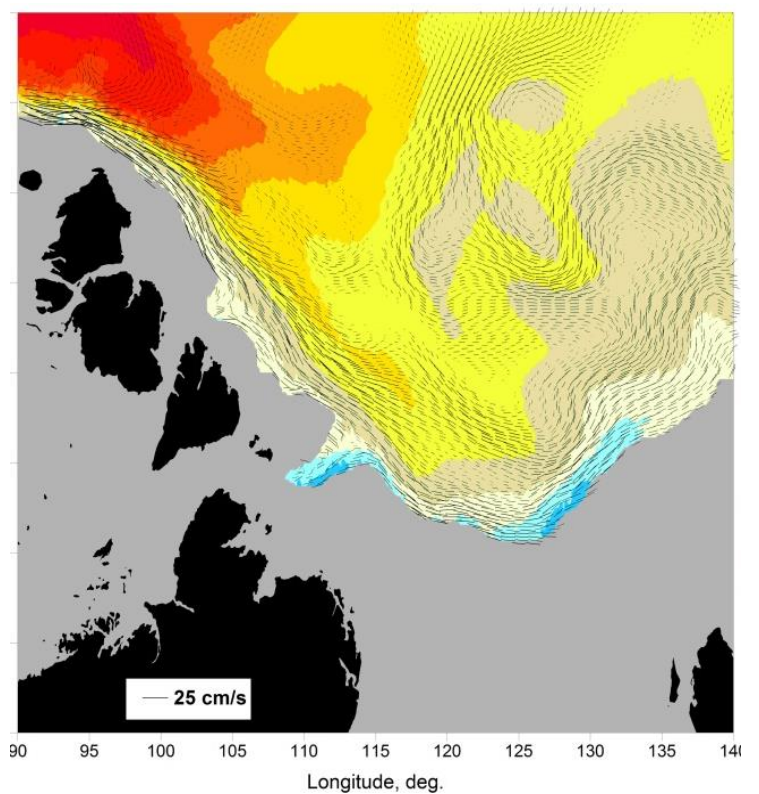

Figure 5. Model distribution of monthly mean temperature, ${ }^{\circ} \mathrm{C}$, and current speed, $\mathrm{cm} / \mathrm{s}$ at $250 \mathrm{~m}$ depth in September, 1986 (a) and 2007 (b).

Sequential temperature maps at $250 \mathrm{~m}$ from September 2006 to September 2007 are

presented in Figure 6. There is no noticeable difference in location and intensity of the cold water zones from September 2006 (a) through February 2007 (b). An elongated spot with the temperature slightly below zero is sitting at the slope, in and between two relatively deep tranches, cutting the continental slope of the north-western Laptev Sea at about $78^{\circ} \mathrm{E}$ and $80^{\circ} \mathrm{E}$. This distribution starts changing in March 2007 (c), when the zone with negative temperature extends intermittently northwestwards along the slope, while the minimum temperature goes down. In April 2007 (d) local pockets of substantially colder water $(<-0.7)$ appear within the northern trench. This cold water may not be advected by the boundary current, because there is no signs of water that cold upstream. 
(a)

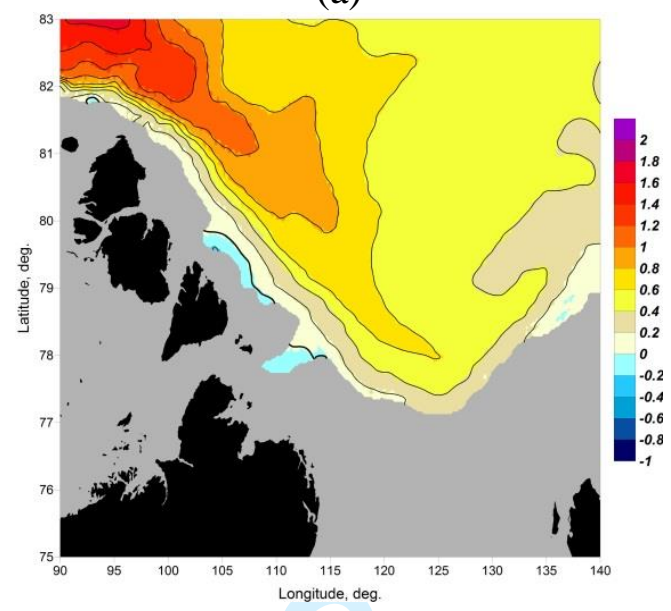

(b)

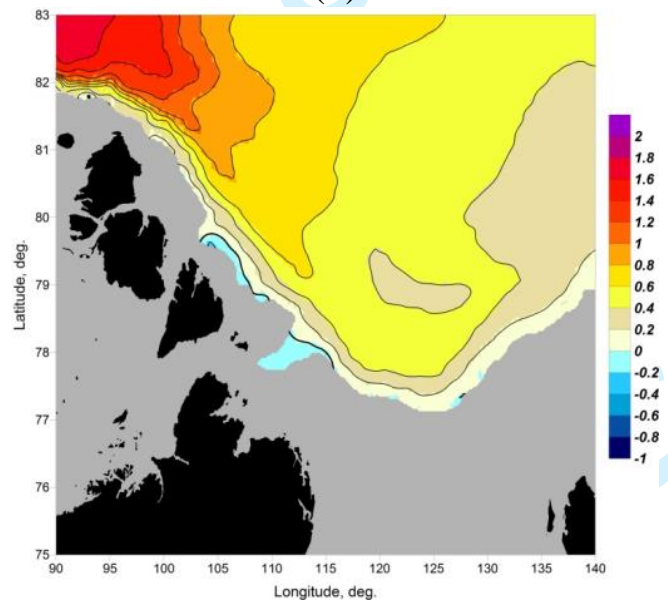

(c)

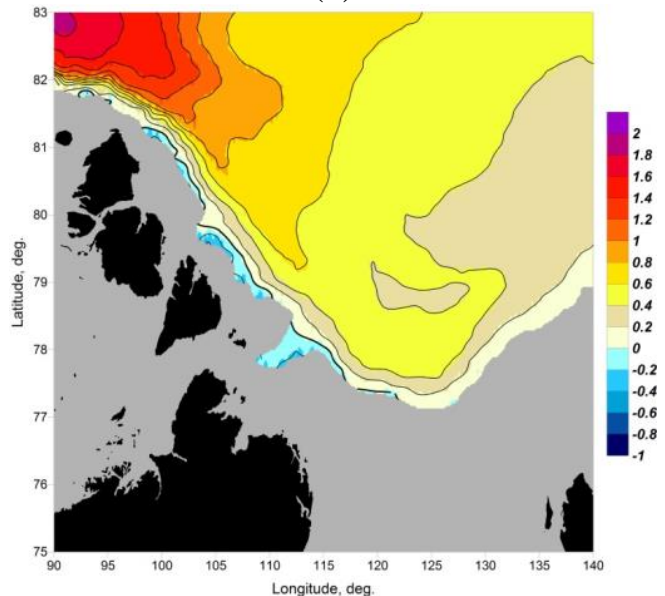

(d) (e)

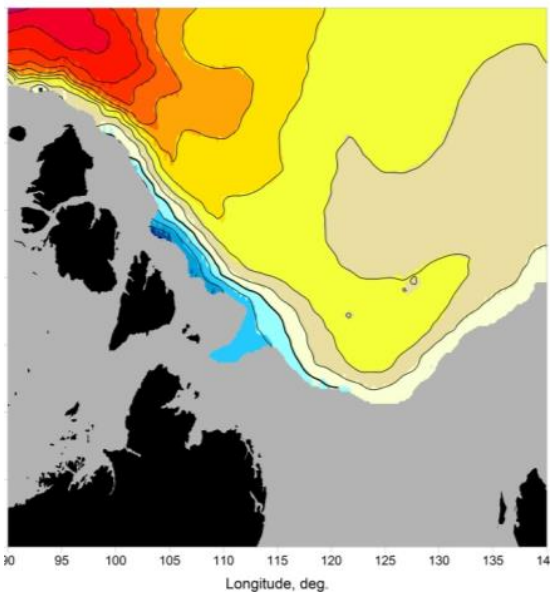

(f)

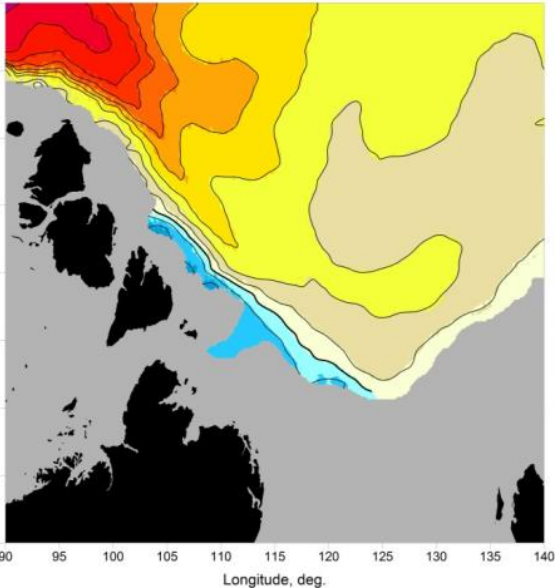

(g)

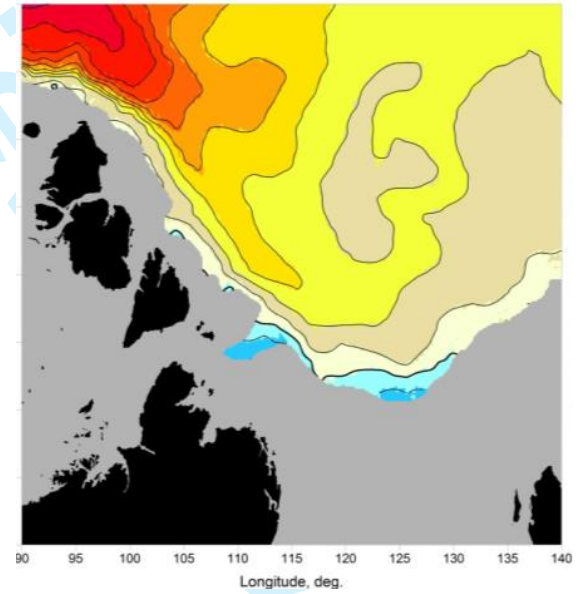

(h) 

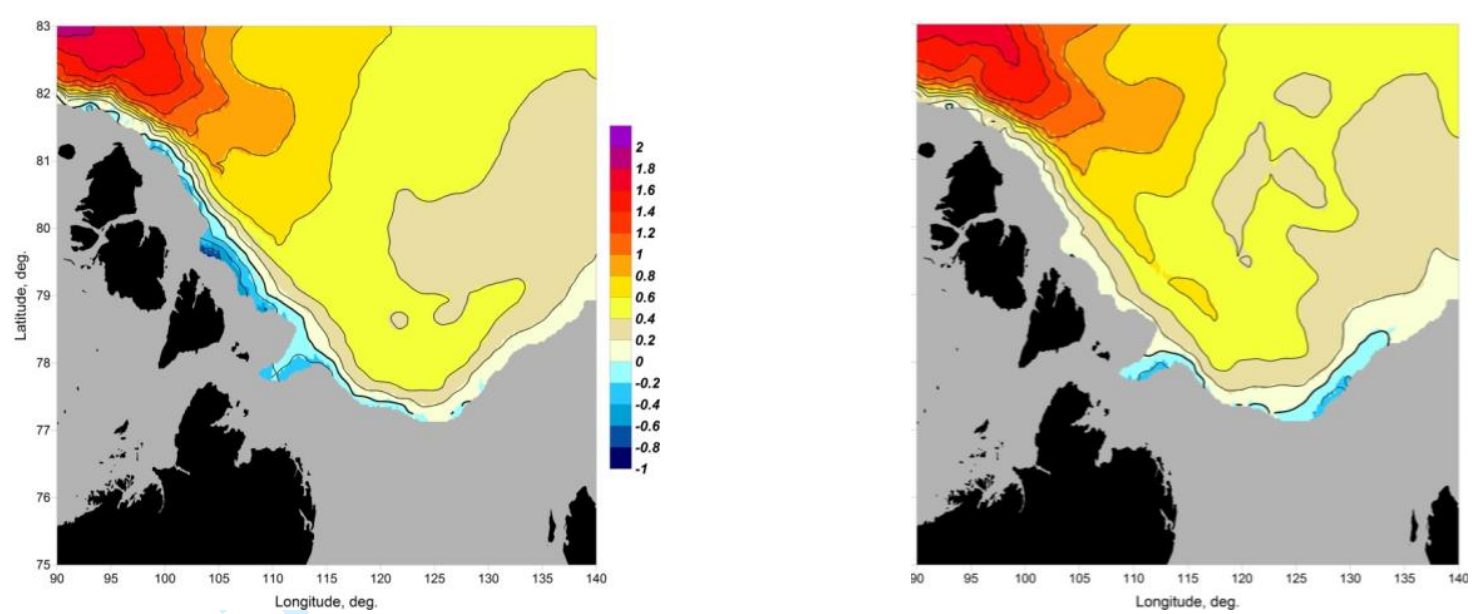

Figure 6. Model temperature distribution $\left({ }^{\circ} \mathrm{C}\right.$ ) at $250 \mathrm{~m}$ throughout 2006-07: (a) Sep-2006; (b) Feb2007; (c) Mar-2007; (d) Apr-2007; (e) May-2007; (f) Jul-2007; (g) Aug-2007; (h) Sep-2007. Contours show smoothed temperature field.

In August (g) and September (h) 2007 the tongue of cold water circulates around the southernmost point of the Laptev Sea shelf and turns with the bathymetry to the north-east. It is important to note, that by September, 2007 there is no cold water in the region of its origin - the trench at $80^{\circ} \mathrm{N}$.

The evolution of cold anomalies, replicated in the model, confirm our working hypothesis of the 'shelf convection - cascading' nature of this phenomenon. According to previous studies, the most suitable site in the Laptev Sea, where dense water, generated in the local polynya, is able to attain sufficient density to cascade as deep as the FAW core, is located on the shelf adjoining the trench at $80^{\circ} \mathrm{N}$ (Ivanov et al. 2004). Depending on the actual atmospheric forcing and parameters of the local polynya (size and frequency of opening through the winter), water with cascading potential may reach various water layers over the neighbouring continental slope (Ivanov and Watanabe 2013). According to modelling results, the most effective leaking of dense water downslope occurs through the trench, invoking compensatory deep water flow on shelf (Ivanov and Golovin 2007). The timing, which is required for dense water to reach the $250 \mathrm{~m}$ depth in the trench at $80^{\circ} \mathrm{N}$ is about 100 days, starting from the point, when shelf convection has totally homogenized the water column over the shallow (about $50 \mathrm{~m}$ depth) bank (Ivanov and Golovin 2007: Figure 10). Applying this timing to the current simulations suggests that to get first indications of new portion of dense water in the trench in March, the shelf convection should mix the water column over the shallow bank by late November - early December. This is entirely feasible, taking into account URL: http:/mc.manuscriptcentral.com/ggaf Email: A.M.Soward@exeter.ac.uk 

3 4 5 6

uncertainties in the polynya dynamics. Formation of dense water on the north-eastern Laptev Sea shelf in winter 2006-07, and down-slope cascading of this water is described in details in the supplement file.

Another result in favour of our concept follows from Figure 7, which shows the time series of maximum and minimum temperature at $250 \mathrm{~m}$ in 1986-87 and 2006-07. Two top lines are rather similar, indicating existence of seasonal cycle in the FAW, which is mostly transported from upstream by the boundary current (Ivanov et al. 2009; Dmitrenko et al. 2009). Time evolution of the 1986-87 temperature minimum also shows well-pronounced seasonal cycle. Although this curve is shifted in phase from the upper lines, there is no indication of any disturbances, associated with specific season. Time evolution of 2006-07 temperature minimum is very different. Instead of quasi-regular seasonal variation, there is rapid temperature drop, starting in March with culmination in May, and restoration in July to the numbers, close to those in the previous September.

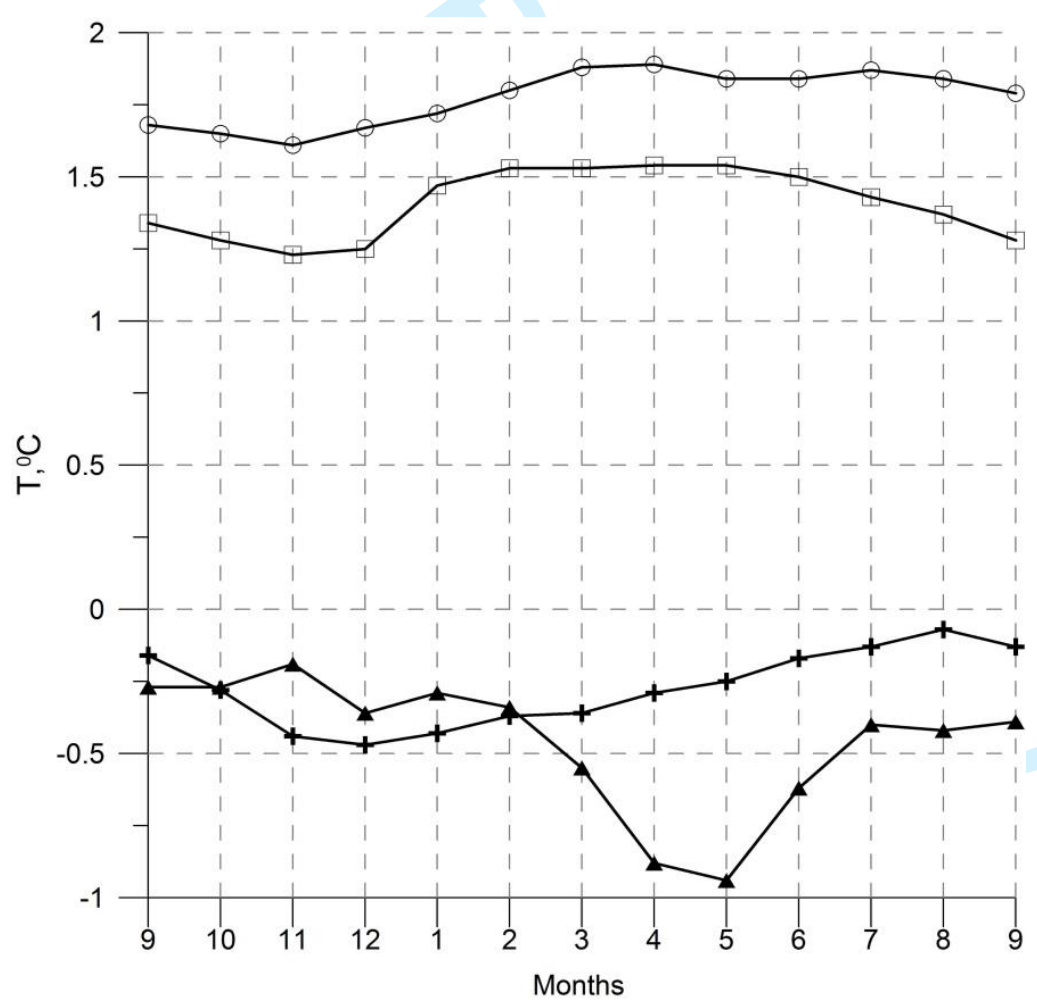

Figure 7. Time series of maximum and minimum temperature at $250 \mathrm{~m}$ depth in $1986-87$ and 200607: $\mathrm{T}_{\max }$ in 1986-87 - open squares; $\mathrm{T}_{\max }$ in 2006-07 - open circles; $\mathrm{T}_{\min }$ in 1986-87 - crosses; $\mathrm{T}_{\min }$ in 2006-07 - triangles. 
Evidence of intensive cascading development in the north-western Laptev Sea in April

2692007 is provided by vertical temperature and salinity distribution across the continental slope.

270 Vertical sections along $80^{\circ} \mathrm{N}$ in April 1987 and 2007 are presented in Figure 8. The difference in the 9

(a)

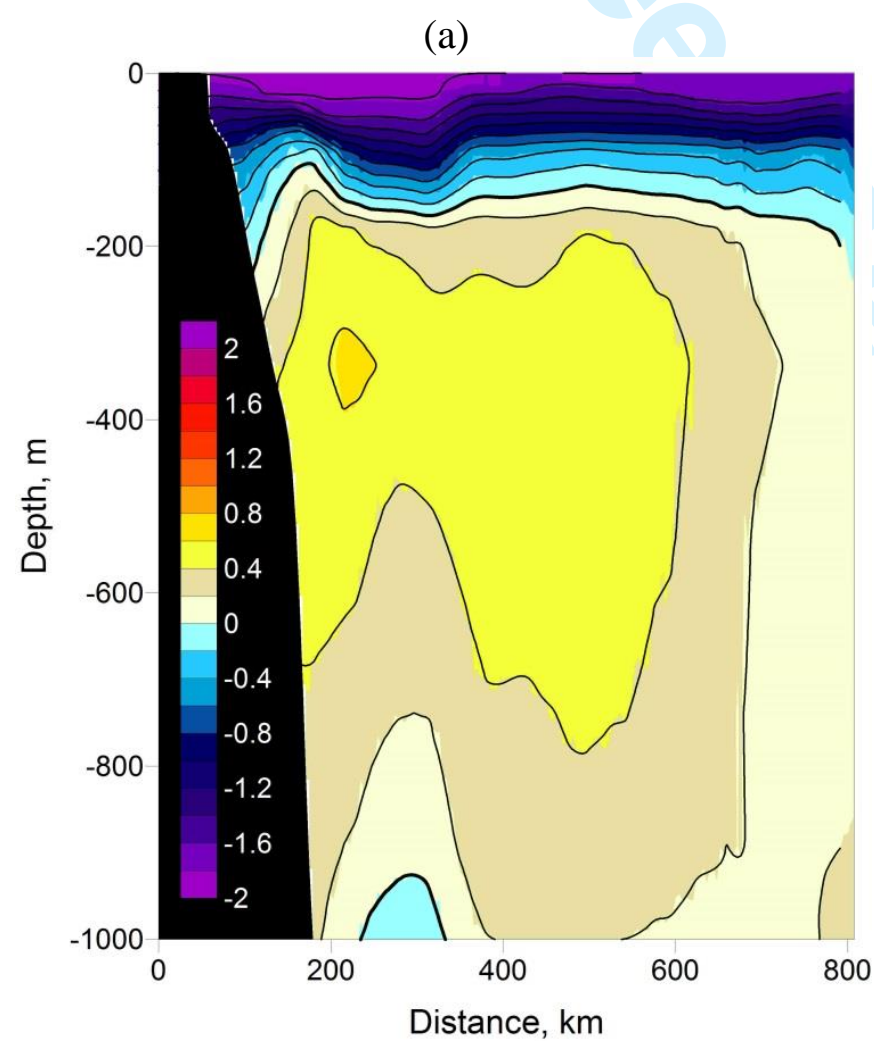

(c)

pattern of thermohaline properties at the slope is very well distinguished in these plots. In April,

1987 relatively strong halocline (0.3 PSU) separates the water at the $100 \mathrm{~m}$ depth from the cold

(near to freezing temperature) and fresher water at the surface (b). In April 2007, almost

homogeneous water layer with salinity around 34.55 PSU is reaching the depth of $350 \mathrm{~m}$ (Figure 8, c), thus allowing deep penetration of the cold water from the surface (d). As a result, in April 1987, warm Atlantic water (with temperature above zero) is bordering the slope at about $200 \mathrm{~m}$ depth, while in 2007 this water is detached from the slope down to the depth of $400 \mathrm{~m}$ (Figure 8, b, d).

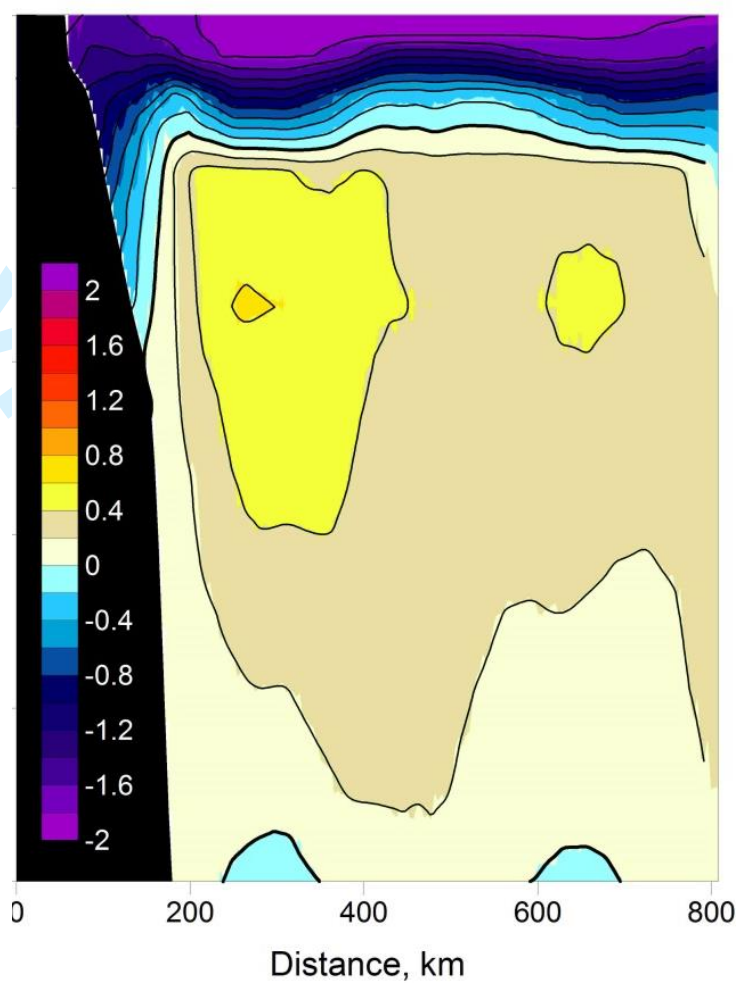

(d) 

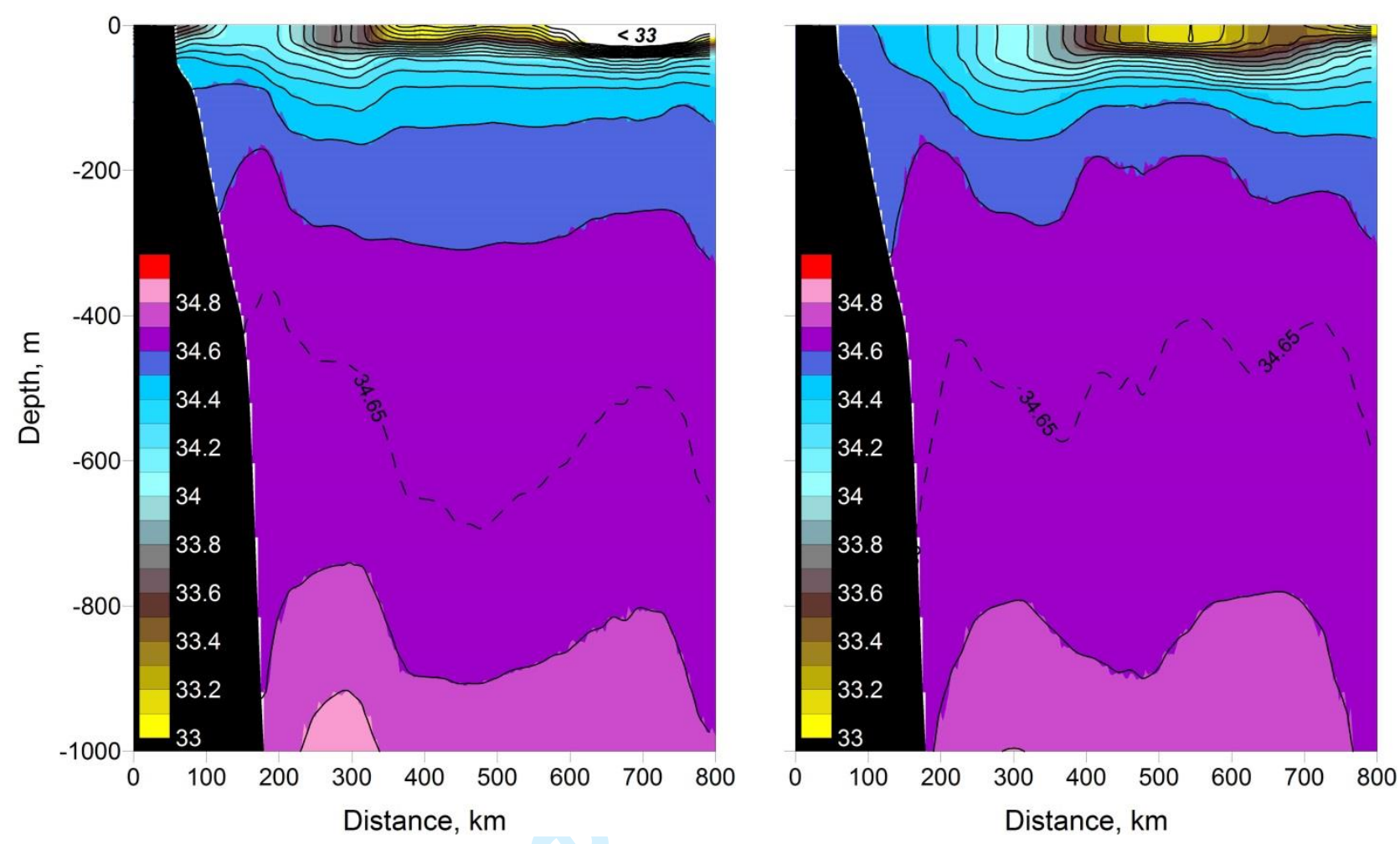

Figure 8. Temperature $\left({ }^{\circ} \mathrm{C}\right.$ ) and salinity (PSU) distribution at the vertical section along $80^{\circ} \mathrm{N}$ in April 1987 (a,c) and in April 2007 (b,d) respectively.

\section{Shelf-basin fluxes}

Change in the intensity of shelf-basin exchange between late winter - spring 1986-87 and 2006-07, depicted in the previous section, is quantified by cross-slope fluxes of volume, heat and salt, calculated in accordance with formula (*) for the region, marked by the polygon in Figure 1. Vertical distribution in Figure 9 shows horizontally averaged specific fluxes per unit square, which is oriented perpendicular to the bottom topography gradient. Spatial step, used in calculations was taken equal to $50 \mathrm{~m}$ for the depth range $0-500 \mathrm{~m}$, and $100 \mathrm{~m}$, from 500 to $1000 \mathrm{~m}$ depth. Offshore direction is defined as the positive one.

Specific volume flux $(\mathrm{m} / \mathrm{s})$ in this case is equivalent to the cross-topography component of the flow speed. As follows from Figure $9(a, d)$, the plane of the transect in both years is divided into two zones with opposite direction of cross-isobath flow. In the deeper part, which is roughly

291 bounded by $350 \mathrm{~m}$ depth at the slope, the flow is directed onshore with maximum speed near the 292 deep end of the transect. The largest difference between the two studied years is observed in the 
293 shallow corner of the transect. In April, 1987 the zone of positive (offshore) flow is confined to 4

5294 small region around $200 \mathrm{~m}$ depth at the slope (a), while in April 2007, there is much more extended

(a)

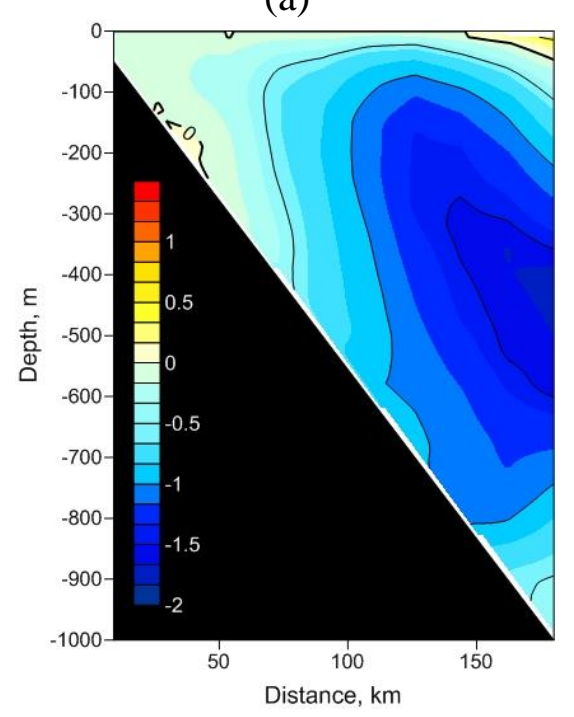

(b)

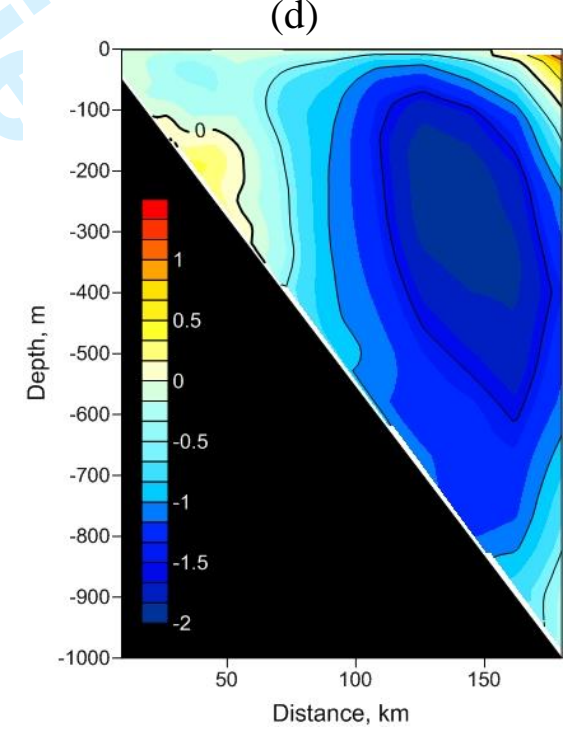

(e) 


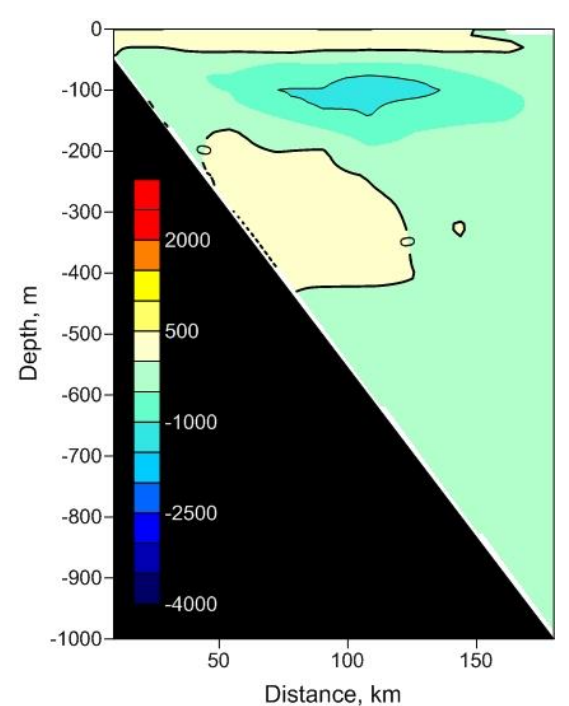

(c)

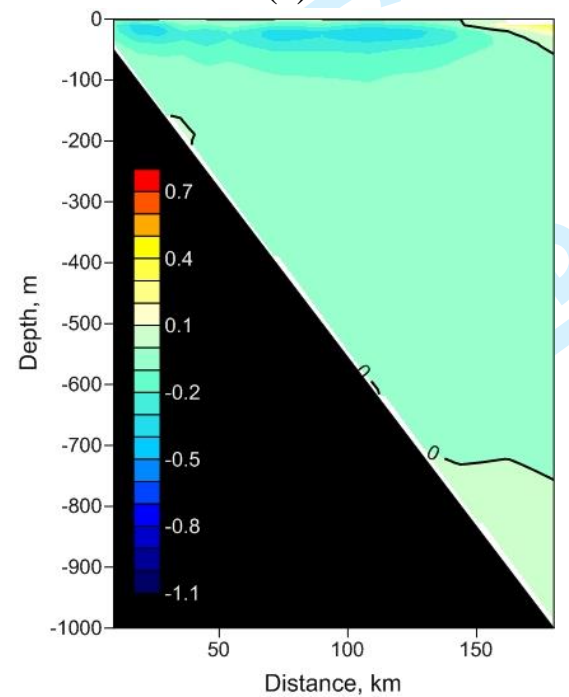

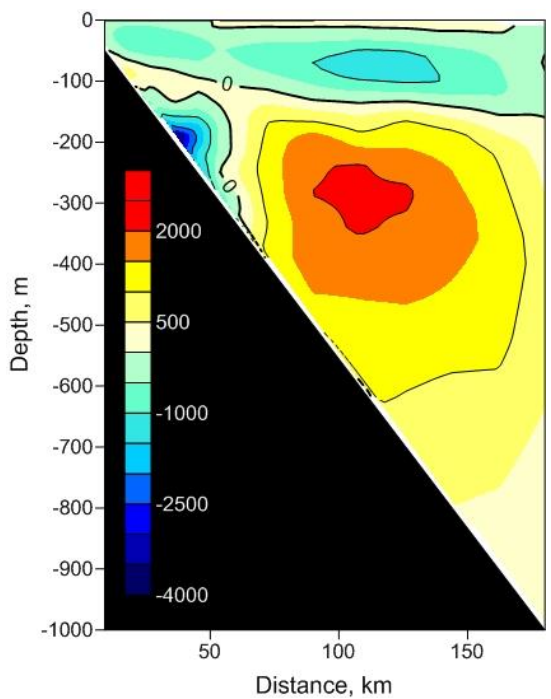

(f)

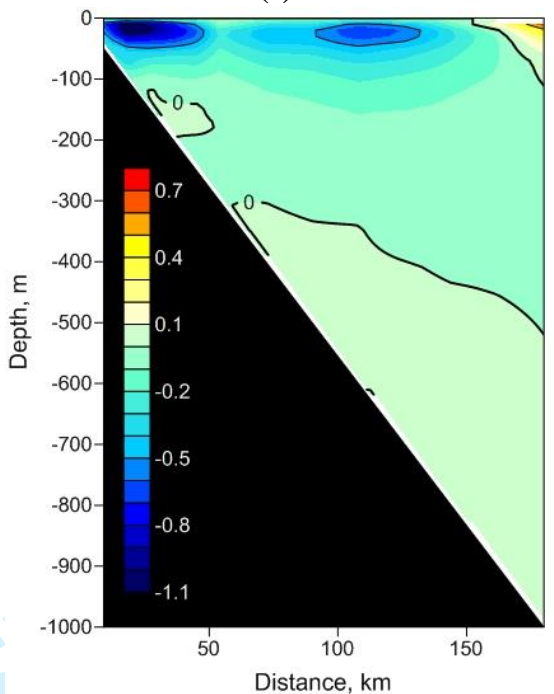

Figure 9. Vertical distribution of mean cross-slope speed of flow, $\mathrm{m} / \mathrm{s}(\mathrm{a}, \mathrm{d})$; specific heat flux, $\mathrm{W} / \mathrm{m}^{2}$ (b, e); salt flux, g/m/s (c, f) in March - May 1987 and 2007. Spatial averaging is done over depth contours with lateral bounds, shown in Figure 1.

Negative heat flux above 100 m reflects the onshore flow of warmer water from the deep basin. In the shallow part of the transect ( $0-70 \mathrm{~km}$ distance) this heat flux is probably associated with compensatory upwelling, which accompanies cascading (Ivanov and Golovin 2007). The deep zone with positive heat flux probably reflects the heat exchange within FAW, which is characterised by stronger temperature irregularity in April, 2007, compared to April, 1987.

Salt flux associated with cascading in the Laptev Sea typically changes sign with increasing depth (Ivanov and Golovin, 2007). This happens because of salinity stratification, which 316 passing the halocline, and fresher when reaching the salty FAW core (see Figure 8-d). This is 
reflected in Figure 9-f by the compact zone with positive salt flux around $200 \mathrm{~m}$ depth on the slope and small negative flux further down the slope. High negative salt flux near the surface in both years is associated with onshore motion of salty water from the basin, which is stronger in April 2007, because of compensatory upwelling.

Overall, the analysis of cross-slope fluxes of volume, heat and salt points out that in April 2007 the intensity of shelf-basin exchange was substantially higher, than in April 1987. This difference was especially pronounced at the upper slope and was associated with more intensive development of cascading. Quantitatively, mean fluxes in two compared cases (April, 1987 and April, 2007) were: speed of the flow was $0.38 \mathrm{~m} / \mathrm{s}$ and $0.44 \mathrm{~m} / \mathrm{s}$; specific heat flux was $71 \mathrm{~W} / \mathrm{m}^{2}$ and $246 \mathrm{~W} / \mathrm{m}^{2}$; specific salt flux was $0.018 \mathrm{~g} / \mathrm{m}^{2 /} \mathrm{s}$ and $0.034 \mathrm{~g} / \mathrm{m}^{2} / \mathrm{s}$ correspondingly. The obtained results and the limits of their applicability for the seasonally ice free Arctic Ocean are discussed in the next section.

\section{Discussion and conclusions}

Accelerated reduction of the summer ice cover after 2007 led to the dominance of the firstyear ice in the Arctic Ocean. Overall result of this tendency (if sustained, as predicted in the recent CMIP5 model simulations, cited in the Introduction, and in the IPCC report (2007)), will be increased seasonal range of ice cover and thinner, more fragile sea ice in winter. In this model study we examined, how such changes in the ice cover properties may affect the shelf-basin exchange due to expected intensification of dense water formation on shelf and cascading of this dense water to the adjacent deep basin. We targeted the north-western shelf-slope region in the Laptev Sea, because of its well-known high potential to produce sufficiently dense water in the past. The monthly mean output of the NEMO-LIM2 model experiment was analysed for two years with very different ice conditions: 'icy' 1986-87 and 'ice-free' 2006-07. Analysis of temperature distribution at the depth of the FAW maximum in the Laptev Sea $(250 \mathrm{~m})$ have demonstrated visible increase of the amount of the local origin cold water in late winter 2007 in the region, where this dense water typically appears as a result of its formation on shelf and downslope leaking. Time evolution of the 
minimum temperature at the $250 \mathrm{~m}$ depth revealed a radically different shape of the temperature minimum curve in 2007 compared to that in 1986-87. The later one exhibits quasi-regular seasonal cycle, similar to the time evolution of maximum temperature in both studied years. In 2007 the seasonal cycle is disturbed by a strong decrease of minimum temperature in March-June, which coincides with the timing, when dense water cascading is at its maximum (Shapiro et al. 2003). Quantitative analysis of the shelf-basin exchange during March-May in both years on the basis of calculated volume, heat and salt fluxes confirmed a substantial increase of fluxes in 'ice-free' 2007 compared to the 'icy' 1987, on the average by 2 times.

According to several past model studies, dense water production on Arctic shelves in winter, driven by ice freezing and salt ejection is not likely to cease in a warmer climate, but rather the opposite (Bitz et al. 2008, Ivanov and Watanabe 2013). There is also observational evidence that cascading in the seasonally ice covered seas (e.g. the Barents Sea) is much more efficient than it is in the permanently ice covered Arctic Ocean (Ivanov and Shapiro 2005). This gives us some confidence that presented results are reasonable and have to be taken into account in future climate scenarios. However, we acknowledge that such predictions should be considered with caution, because of several uncertainties, which are caused by not taking into account in this study probable additional 'actors'. First of all, the obtained results might be affected by the changing fresh water content in the surface layer, which is likely going to increase due to excess summer melting. Whether this extra fresh water stays in the area, where ice melted, or will be moved by surface currents to the other region of the Arctic Ocean, or even, out of the Arctic Ocean (Mauritzen 2012), is an open question? Recent observation-based studies (Morrison et al. 2012) suggest that, so far, the excess melting and river runoff has led to substantial increase of fresh water content in the Canadian Arctic, while in the Atlantic sector the opposite trend is true and a. moderate salinity increase is observed (MacPhee et al. 2009). As was pointed out in the introduction, the necessary condition for effective dense water formation on shelf is the high frequency occurrence of strong winds in a certain direction, which is able to break ice and open polynyas. Whether the wind pattern is going to substantially change in the warmer climate is uncertain. We may only speculate that 
under the given wind forcing the thinner ice, which is expected to dominate in the warmer climate, could be easily broken and moved. As for the two analysed years, the SLP fields in the corresponding winter months, reconstructed from the NCEP-NCAR reanalysis products (http://www.esrl.noaa.gov/psd/data/gridded/data.ncep.reanalysis.htm ), do not substantially differ. In the beginning of this paper we also mentioned wind upwelling as the possible important contributor to the shelf basin exchange in summer season under the depleted ice cover. We compared the results of model calculation in summer months of 1987 and 2007 with respect to possible upwelling intensification. However, no significant changes were found. This does not mean that the concept of intensified upwelling in the warmer climate is compromised by this study. We rather conclude that the reason behind this is the overestimation by the model of the summer ice coverage in the Laptev Sea in 2007 (see Figure 4- c, f).

Acknowledgements. Authors would like to express their deep respect to Professor John Huthnance, M.B.E. of the National Oceanographic Centre, whose fundamental contribution to the theory of dense water cascading in the World Ocean inspired this investigation. We would like to thank our former colleague Beverly de Cuevas from the National Oceanography Centre (NOC) for performing model experiments. In AARI this study was supported by RFBR grant 13-05-41443 "Extreme atmospheric events in the polar regions and its connection to changes in ice conditions". At the NOC this study was supported by the UK Natural Environment Research Council through the Marine Centres' Strategic Research Programmes and is a contribution to the Arctic Research Programme TEA-COSI project (Project ID: NE/I028947/1). The NOCS-ORCA simulations were undertaken as part of the DRAKKAR collaboration (Barnier et al. 2006). NOC also acknowledges the use of UK National High Performance Computing Resource. V. Ivanov is grateful to IARC director Larry Hinzman for the given opportunity to finalize this paper during his two-month visit in Fairbanks. 
Aagaard, K., L.K. Coachman and E. Carmack. On the halocline of the Arctic Ocean. Deep Sea Res. 1981. 28A. 529-545.

Aksenov, Y., V. Ivanov, G. Nurser, S. Bacon, I. Polyakov, A. Coward, A. Naveira-Garabato, and A. Beszczynska-Möller. The Arctic Circumpolar Boundary Current, J. Geophys. Res., 2011. 116. C09017, doi:10.1029/2010JC006637.

Bareiss, J. and K. Goergen. Spatial and temporal variability of sea ice in the Laptev Sea: Analysis and review of satellite passiv-microwave data and model results, 1997 to 2002. Global and Planetary Change. 2005. 48. 28-54.

Barnier, B., G. Madec, T. Penduff, J. M. Molines, A. M. Treguier, J. Le Sommer, A. Beckmann, A. Biastoch, C. Böning, J. Dengg, C. Derval, E. Durand, S. Gulev, E. Remy, C. Talandier, S. Theetten, M. Maltrud, J. McClean, and B. A. de Cuevas., Impact of partial steps and momentum advection schemes in a global ocean circulation model at eddy permitting resolution. Ocean Dyn. 2006. 56, 543-567. doi: 10.1007/s10236-006-0082-1.

Bitz, C.M., P.R. Gent, R. A. Woodgate, M. M. Holland and R. Lindsay. The influence of sea ice on ocean heat uptake in response to increasing CO2. 2008. Journ. of Climate. 19. 2437-2450.

Carmack, E. and D.C. Chapman). Wind-driven shelf/basin exchange on an Arctic shelf: The joint roles of ice cover extent and shelf-break bathymetry. Geophys. Res. Lett. 30. 14. 1778. doi:10.1029/2003GL017526.

Cavalieri, D., C. Parkinson, P. Gloersen and H. J. Zwally. Sea Ice Concentrations from Nimbus-7 SMMR and DMSP SSM/I-SSMIS Passive Microwave Data, 1979-2010. 1996, updated yearly. Boulder, Colorado USA: National Snow and Ice Data Center. Digital media.

Dethleff, D. Linear model estimates of potential salt rejection and theoretical salinity increase in a standardized water column of recurrent Arctic flaw leads and polynyas. Cold Reg. Sci. and Technol. 2010. 61. 82-89.

Dmitrenko, I. A., S. A. Kirillov, L. B. Tremblay, D. Bauch, J. A. Hölemann, T. Krumpen, H. Kassens, C. Wegner, G. Heinemann and David Schröder. Impact of the Arctic Ocean 
Atlantic water layer on Siberian shelf hydrography. Journ. Geophys. Res. 2010a. 115. C08010. doi:10.1029/2009JC006020.

Dmitrenko, I. A., S. A. Kirillov, T. Krumpen, H., M. Makhotin, E. P. Abrahamsen, S. Willmes, E. Bloshkina, H. Kassens, C. Wegner. Wind-driven diversion of summer river runoff preconditions the Laptev Sea coastal polynya hydrography: Evidence from summer-towinter hydrographic records of 2007-2009. Cont. Shelf Res. 2010b. 30. 1656-1664.

Dmitrenko, I., S. Kirillov, V. Ivanov, R. Woodgate, I. Polyakov, N. Koldunov, L. Fortier, C. Lalande, L. Kaleschke, D. Bauch, J. Hölemann, and L. Timokhov. Seasonal modification of the Arctic Ocean intermediate water layer off the eastern Laptev Sea continental shelf break. Journ. of Geophys. Res. 2009. 114. C06010. doi:10.1029/2008JC005229.

Encyclopaedia Britannica. Encyclopaedia Britannica Online Academic Edition. Encyclopædia Britannica Inc. 2014. Available online at: www.britannica.com/EBchecked/topic/637132/water-mass (Accessed . March 17 2014).

Environmental Working Group (EWG): Joint U.S.-Russian Atlas of the Arctic Ocean (CD-ROM). 1997, 1998. National Snow and Ice Data Centre, Boulder, Co. USA.

Fichefet, T., and M. A. M. Maqueda. Sensitivity of a global sea ice model to the treatment of ice thermodynamics and dynamics, Journ. of Geophys. Res.-Oceans. 1997. 102. 12609-12646.

Frolov S.V., V.E. Fedyakov, V.Yu Tretyakov, A.E. Klain and G.V. Alexeev. New data on ice thickness changes in the Arctic basin. Doklady Earth Sciences (Doklady Akademii Nauk). 2009. 425 (1). 104-108.

IPCC Forth Assessment Report: Climate Change 2007 (AR4). Available online at: www.ipcc.ch/publications_and_data/publications_and_data_reports.htm (Accessed: March 17 2014).

Ivanov, V.V., G.I. Shapiro, J.M. Huthnance, D.L. Aleynik and P.N. Golovin. Dense water cascades around the World Ocean. Progr. Oceanogr. 2004. 60. 47-98. 
Ivanov, V.V. and P.N. Golovin. Observations and modeling of dense water cascading from the Laptev Sea shelf. Journ. of Geophys. Res. 2007. 112. C09003. doi:10.1029/2006JC003882.

Ivanov, V.V., I.V. Polyakov, I.A. Dmitrenko, E. Hansen, I.A. Repina, S.S. Kirillov, C. Mauritzen, H. Simmons, L.A. Timokhov. Seasonal Variability in Atlantic Water off Spitsbergen. Deep Sea Res. Part I. 2009. 56. 1-14. doi:10.1016/j.dsr.2008.07.013.

Ivanov V.V. and E. Watanabe. Does Arctic sea ice reduction foster shelf-basin exchange? Ecological Applications, 2013. 23(8). 1765-1777.

Ivanov, V.V. and Ye. Aksenov. Atlantic Water transformation in the eastern Nansen Basin: observations and modelling, Probleme Arctiki i Antarctiki. 2013. 1 (95). $72-86$ (in Russian with English abstract).

Jackson, J.M., C. Lique. M. Alkire, M. Steele. C.M. Lee, W.M. Smethie and P. Schlosser. On the waters upstream of Nares Strait, Arctic Ocean, from 1991 to 2012. Cont. Shelf Res. 73. 8396. ISSN 0278-4343. Available online at: http://dx.doi.org/10.1016/j.csr.2013.11.025 (Accessed: March 17 2014).

Jahn, A., Ye. Aksenov, B.A. de Cuevas, L. de Steur, S. Häkkinen, E. Hansen, C. Herbaut, M.-N. Houssais, M. Karcher, F. Kauker, C. Lique, A. Nguyen, P. Pemberton, D. Worthen, and J. Zhang. Arctic Ocean freshwater: How robust are model simulations? Journ. Geophys. Res. 2012. 117. C00D16. doi:10.1029/2012JC007907.

Johnson, M., A. Proshutinsky, Ye. Aksenov, A. YT. Nguyen, R. Lindsay, C. Haas, J. Zhang, N. Diansky, R. Kwok, W. Maslowski, S. Hakkinen, I. Ashik, and B. de Cuevas. Evaluation of Arctic sea ice thickness simulated by Arctic Ocean Model Intercomparison Project models. Journ. of Geophys. Res. 2012. 117. C00D13.doi:10.1029/2011JC007257

Kampf, J. (2005). Cascading-driven upwelling in submarine canyons in high latitudes. J. Geophys. Res., 110, C02007, doi:10.1029/2004JC002554. 
Karcher, M., Smith, J. N., Kauker, F., Gerdes, R., and Smethie, W. M.. Recent changes in Arctic Ocean circulation revealed by iodine- 129 observations and modeling. J. Geophys. Res. 117(C8). 2012.

Krumpen, T., M. Janout, K. I. Hodges, R. Gerdes, F. Girard-Ardhuin, J. A. Holemann and S. Willmes. Variability and trends in Laptev Sea ice outflow between 1992 - 2011. Available online at: www.the-cryosphere-discuss.net/6/C2777/2013/tcd-6-C2777-2013supplement.pdf (Accessed: March 17 2014).

Kwok, R., C.F. Cunningham, M. Wesnahan, I. Rigor, H.J. Zwally, and D. Yi. (2009). Thinning and volume loss of the Arctic Ocean ice cover: 2003-2008, J. Geophys. Res. 114, C07005, doi:10.029/2009JC005312.

Lique, C. A. M. Treguier, M. Scheinert, and T. Penduff. A model-based study of ice and freshwater transport variability along both sides of Greenland. Clim. Dyn. 2009. 33. 685-705, doi:10.1007/s00382-008-0510-7.

Lique, C. and M. Steele. Where can we find a seasonal cycle of the Atlantic water temperature within the Arctic Basin? Journ. Geophys. Res. 2012. 117. C03026. doi:10.1029/2011JC007612.

Madec, G., M. Delecluse, M. Imbard, and C. Levy. OPA version 8.1 ocean general circulation model reference manual. Tech. Rep. 1998. 91 pp. Available online at: www.nemoocean.eu (Accessed: March 17 2014).

Maqueda, M.A., A.J. Willmott and N.R.T. Biggs. Polynya dynamics: a review of observations and modelling. Rev. Geophys. 2004. 42. RG1004.

Martin, S., Cavalieri, D.J. Contributions of the Siberian shelf polynyas to the Arctic Ocean intermediate and deep water. Journ. of Geophys. Res. 94. C9, 12725- 12738.

Mauritzen, C. Arctic freshwater. Nature Geoscience. 2012. 5. 162-164. 
McPhee, M.G., A. Proshutinsky, J. H. Morison, M. Steele and M. B. Alkire. Rapid change in freshwater content of the Arctic Ocean. Geophys. Res. Lett. 2009. 36. L10602 doi:10.1029/2009GL037525.

Morrison, J., R. Kwok, C. Perralta-Ferris, M. Alkire, I. Rigor and M. Steele. Changing Arctic Ocean freshwater pathways. Nature. 2012. 481. 66-70. doi.10.10308/nature10705.

Nikiforov, Ye. G., and A. O. Shpaikher, Features of the formation of hydrological regime largescale variations in the Arctic Ocean. 1980. (Gydrometeoizdat, Leningrad) (in Russian).

Pease, C.H. The size of wind-driven coastal polynyas. Journ. of Geophys. Res. 1987. 92. C7. 70497059.

Pickart, R.S., G.W.K. Moore, D.J. Torres, P.S. Fratantoni, R.A. Goldsmith, and J. Yang. Upwelling on the continental slope of the Alaskan Beaufort Sea: Storms, ice, and oceanographic response. Journ. of Geophys. Res. 2009. 114, C00A13. Available online at: www.dx.doi.org/10.1029/2008JC005009 (Accessed: March 17 2014).

Polyakov I., A. Beszczynska, E,C. Carmack, I.A. Dmitrenko, E. Fahrbach, I.E. Frolov, R. Gerdes, E. Hansen, J. Holfort, V.V. Ivanov, M.A. Johnson, M. Karcher, F. Kauker, J. Morison, K.A. Orvik, U. Schauer, H.L. Simmons, Ø. Skagseth, V.T. Sokolov, M. Steele, L.A. Timokhov, D. Walsh and J.E. Walsh J.E. One more step towards a warmer Arctic. Geophys. Res. Lett. 2005. 32. L17605. 1-4. doi: 10.1029/2005GL023740.

Proshutinsky A.Y.and Johnson M.A. Two circulation regimes of the wind driven Arctic Ocean. Journ. Geophys. Res. 1997. 102. 12493-12514.

Proshutinsky, A., Ye. Aksenov, J. Clement-Kinney, R. Gerdes, E. Golubeva, D. Holland, G. Holloway, A. Jahn, M. Johnson, E. Popova, M. Steele, and E. Watanabe. Recent advances in Arctic Ocean studies employing models from the Arctic Ocean Model Intercomparison Project. Oceanography. 2011. 24. 102-113.

Rainville, L., C.M. Lee, and R.A. Woodgate. Impact of wind-driven mixing in the Arctic Ocean. Oceanography. 2011. 24(3).136-145. Available online at: www.dx.doi.org/10.5670/oceanog.2011.65 (Accessed: March 17 2014). 
Rudels, B., E.P. Jones, L.G. Anderson, and G. Kattner. On the intermediate depth waters in the Arctic Ocean. In: The Polar Oceans and their Role in Shaping the Global Environment, AGU Geophys. Monograph 85, edited by O.M Johannessen, R.D. Muench, and J.E. Overland, pp. 33-46, 1994 (Washington D.C.)

Rudels, B., R.D. Muench, J. Gunn, U. Schauer and H.J. Friedrich. Evolution of the Arctic Ocean boundary current north of the Siberian shelves. Journ. Marine Syst. 2000. 25. 77-99.

Rudels, B. Arctic Ocean circulation and variability - advection and external forcing encounter constraints and local processes. Ocean Science. 2012. 8. 261-286.

Shapiro, G.I., J.M. Huthnance, V.V. Ivanov. Dense water cascading off the continental shelf Journ. of Geophys. Res. 2003. 108. C12. art: no 3390.

Stroeve, J. C., M.C. Serreze, M.M. Holland, J.E. Kay, J. Malanik, A.P. Barrett. The arctic's rapidly shrinking sea ice cover: a research synthesis. Clim. Change. 2011. 110 (3). 1005-1027. Available online at: www.dx.doi.org/10.1007/s10584-011-0101-1 (Accessed: March 17 2014).

Wiese, W., 1948, Morya Sovetskoy Arktiki, 1948. (Moscow-Leningrad) (in Russian).

\section{Figure captions}

Figure1. The study area. Smoothed bottom topography of the shelf-slope is shown by solid lines. Polygon marks the region, where flux calculations were performed.

Figure 2. Time series of ice extent (15\% concentration) according to satellite data: open circles denote winter season (Dec - May), triangles denote summer season (Jun - Nov) (Cavalieri 1996, http://nsidc.org/data/nsidc-0051.html).

Figure 3. Mean monthly ice concentration in 1986-87: September-1986, April-1987, September1987 according to satellite data (a, b, c) and model (d, e, f) respectively.

Figure 4. Mean monthly ice concentration in 2006-07: September-2006, April-2007, September2007 according to satellite data (a, b, c) and model calculations (d, e, f) respectively.

Figure 5. Model distribution of monthly mean temperature, ${ }^{\circ} \mathrm{C}$, and current speed, $\mathrm{cm} / \mathrm{s}$ at $250 \mathrm{~m}$ 
depth in September, 1986 (a) and 2007 (b).

555 Figure 6. Model temperature distribution $\left({ }^{\circ} \mathrm{C}\right)$ at $250 \mathrm{~m}$ throughout 2006-07: (a) Sep-2006; (b) Feb2007; (c) Mar-2007; (d) Apr-2007; (e) May-2007; (f) Jul-2007; (g) Aug-2007; (h) Sep2007. Contours show smoothed temperature field.

Figure 8. Temperature $\left({ }^{\circ} \mathrm{C}\right.$ ) and salinity (PSU) distribution at the vertical section along $80^{\circ} \mathrm{N}$ in April 1987 (a,c) and in April 2007 (b,d) respectively.

Figure 9. Vertical distribution of mean cross-slope speed of flow, m/s (a, d); specific heat flux, W/m2 (b, e); salt flux, g/m/s (c, f) in March - May 1987 and 2007. Spatial averaging is done over depth contours with lateral bounds, shown in Figure 1. 


\section{The differences in the pan-Arctic circulation between September1987 and 2007}

Figure S1 shows the change in the modelled September ocean upper circulation and water temperature at $250 \mathrm{~m}$ depth between 1987 and 2007. The depth corresponds to the upper part of the Atlantic water residing in the Arctic Ocean. The principal difference is that in 1987 Atlantic Water extended farther in the central Arctic Ocean than in 2007, bringing anomalously warm waters in the Amundsen Basin and in the Makarov Basin. According to the model, the upper intermediate ocean circulation in the Arctic Ocean in September 1987 was cyclonic (counter-clockwise), with the Arctic boundary current along the Siberian shelf slope being strong and narrow, consistent with the other high-resolution modelling studies (e.g. Aksenov et al 2011). In the present simulations the boundary current extended all way to the Canada Basin, where the upper part of the current became unstable in the vicinity of the Chukchi Plateau, but still followed cyclonically the Alaskan coast and then the northern shelf slope of the Canadian Arctic Archipelago, finally forming a strong shelf slope jet flowing towards Fram Strait (Figure S1-a). In contrast, in September 2007 most of the warm Atlantic inflow followed the shelf slopes of the Barents and Kara Seas and the temperature of the inflow was higher than in 1987 (Figure S1-a,b). The cyclonic boundary flow along the western Siberian shelf slope was also strong but wider. Two jets branched from the current into the Arctic Ocean interior, one along the Lomonosov Ridge and another along the Mendeleev Ridge with the Arctic boundary current being essentially blocked in the Canada Basin. Instead, the circulation in the Canada Basin from the surface down to ca. $300 \mathrm{~m}$ was anti-cyclonic (clockwise), coinciding with the circulation in the Beaufort Gyre (Figure S1-b). The blocking effect was also simulated in the other models, for more discussion please see e.g., Karcher et al. (2012). Whereas the changes which occurred between 1987 and 2007 in the Arctic boundary current along the shelf slopes of the Kara, Laptev and East-Siberian Seas were due to the combined effects of the intensified shelf-basin exchanges and the variations in the Atlantic water inflow, we attribute the difference in the ocean circulation in the Canada Basin between these two years to the difference in the large-scale wind field in the Arctic, with anti-cyclonic winds in 2007 dominating over the Canada Basin (e.g. 
McPhee et al. 2009; Proshutinsky et al. 2011). More analysis, which is beyond the scope of the present study, is needed to differentiate between local and large-scale causes of the changes in the Arctic Ocean circulation.

\section{Formation of dense water on the north-western shelf of the Laptev Sea}

Mapping of anomaly propagation near the seabed is very helpful when describing cascading events (e.g. Ivanov and Golovin 2007). A brief description of the evolution of thermohaline structure near the seabed on the north-western Laptev Sea shelf is given below and illustrated by Figure S2.

In the fall-early winter 2006 thermohaline convection reaches seabed over shallow banks (about $50 \mathrm{~m}$ depth) between $79^{\circ} \mathrm{N}$ and $81^{\circ} \mathrm{N}$. Throughout November and December temperature drops to the freezing point (Figure S2- j, k) and salinity over the shelf decreases (Figure S2- a,b) because of thermal convection, which mixes up fresher surface water with saltier deep water. In January and February 2007, the spot of near to freezing temperature over the shelf increases in size (Figure S2- 1,m), while salinity is increasing, because of haline convection, induced by ice formation (Figure S2- c, d). From March to May salinity on the shelf is steadily increasing, due to recurrent polynya opening and intensive ice formation. The size of the high salinity area grows and expands offshore and downslope (Figure S2- e, f, g). Downslope and offshore propagation of the dense water plume and its mixing with the surrounding water is also visualized by the drop in temperature of Atlantic water (AW): From November to March, the location of the AW layer is indicated by a positive temperature stripe (Figure S2- $-\mathrm{m}$ ), stretched along the continental margin. Starting from April, the continuity of AW layer is interrupted in the region where dense water intrusions from shelf occur $\left(79-82^{\circ} \mathrm{N}\right)$. The cold segment, sitting in the AW warm pool, moves south-east, indicating the propagation of the intrusion-affected AW portion along the continental margin. The June plots of salinity and temperature (Figure S2- h, p) show the final stage of the process: the high salinity area on the shelf merges with the zone of similar salinity in the deep 
53 water, forming a wide band of high salinity water over shelf and slope. The main dense water pool 54 is incorporated in the AW flow. Its location in June is roughly between $77^{\circ} 30^{\prime} \mathrm{N}$ and $79^{\circ} \mathrm{N}$ (Figure

55 S2- p). It is indicated by low temperature (about $0^{\circ} \mathrm{C}$ ), but could not be identified by salinity, which 56 is about the same is in the core of AW layer at this position. It is also important to note that the

57 thermohaline structure on the shallow shelf to the south of $77^{\circ} 30^{\prime} \mathrm{N}$ has not radically changed

58 throughout the winter of 2006-2007. Extremely low salinity in this area, caused by intensive river

59 water inflow, prevents formation of sufficiently dense water to cascade down the continental slope 60 (Ivanov et al. 2004).

61 
(a)

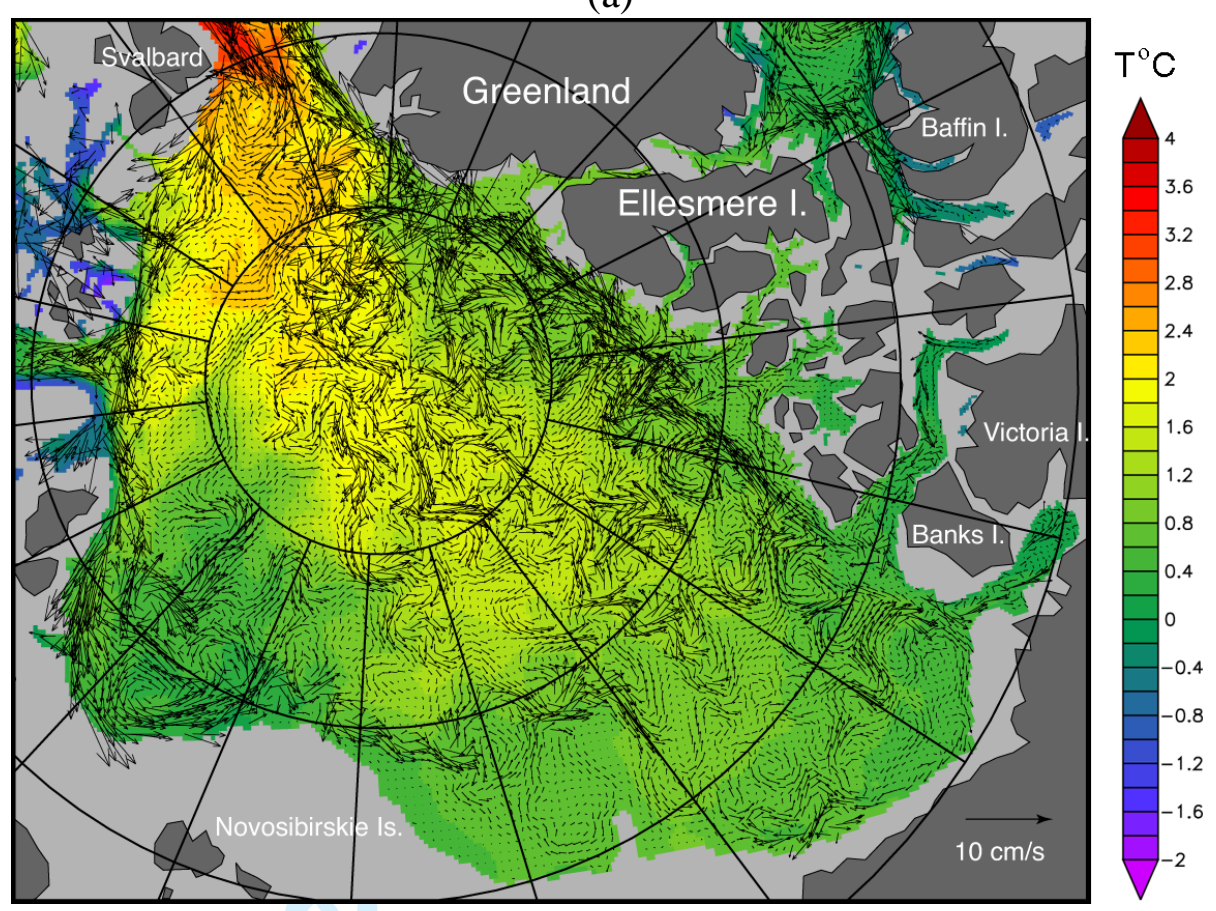

(b)

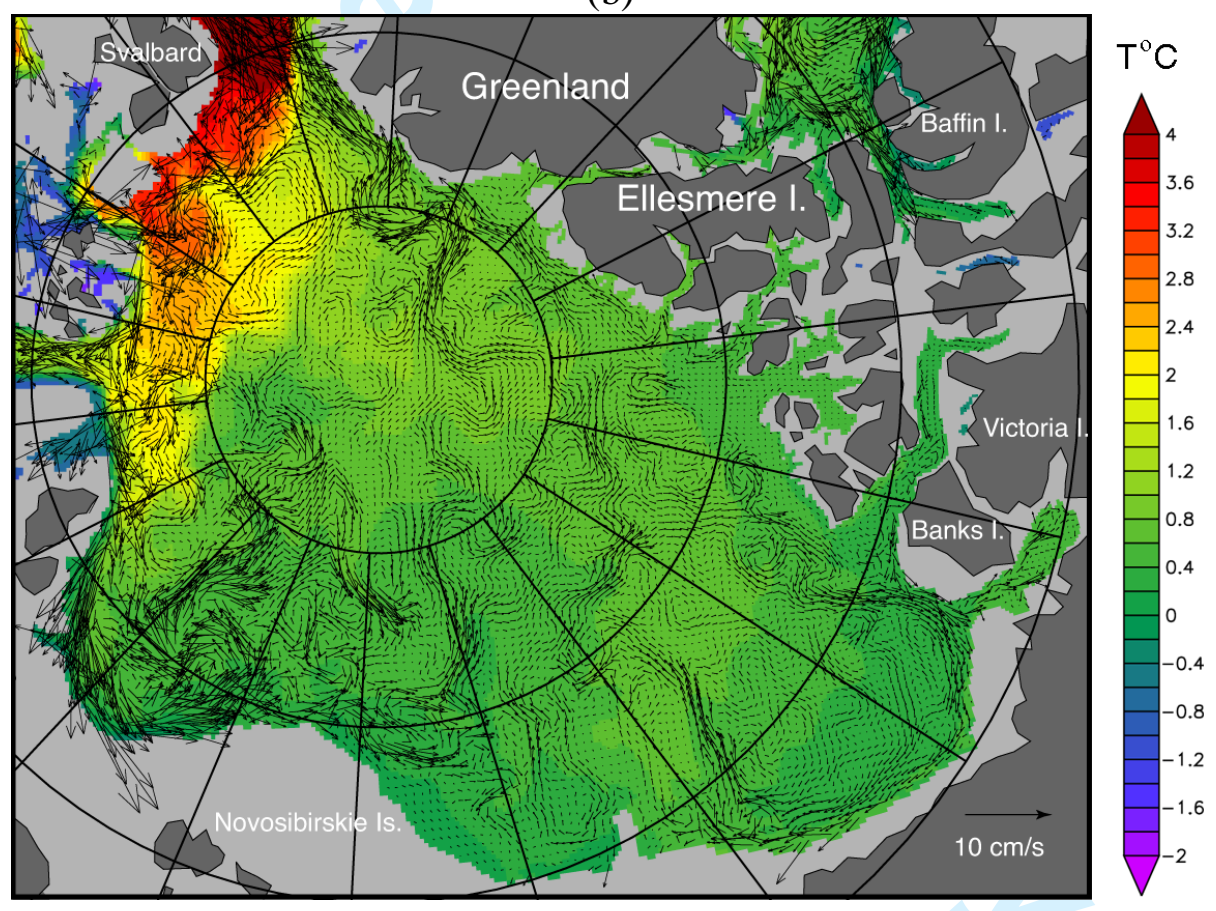

Figure S1. September monthly temperature (colour) and ocean velocity (vectors) at the $250 \mathrm{~m}$ depth in 1987 (a) and 2007 (b). The velocity scale is shown in the insert. Results from the NOCS-ORCA simulations. 
(a)

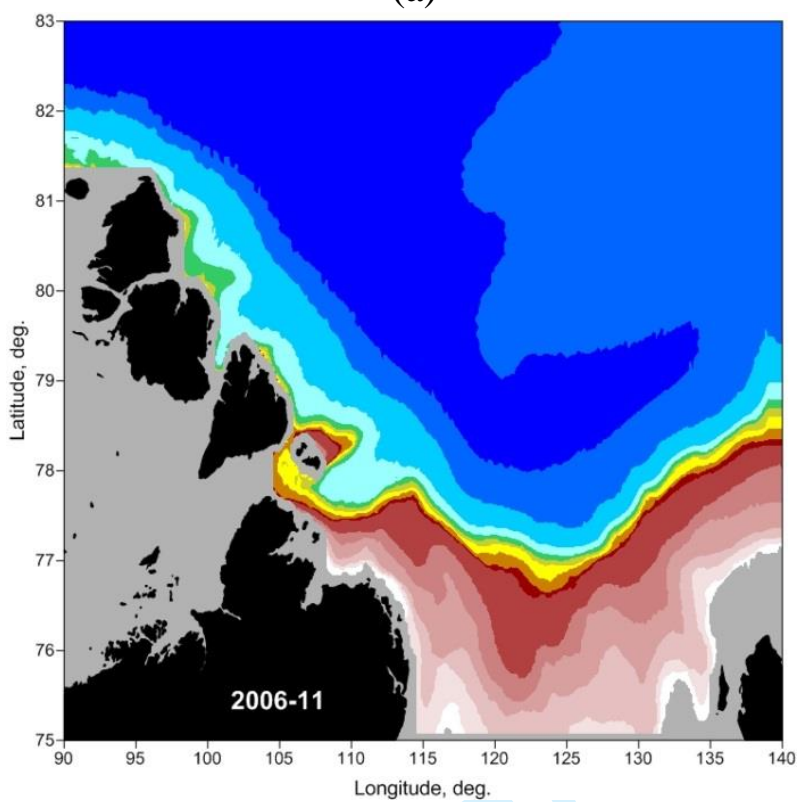

(b)

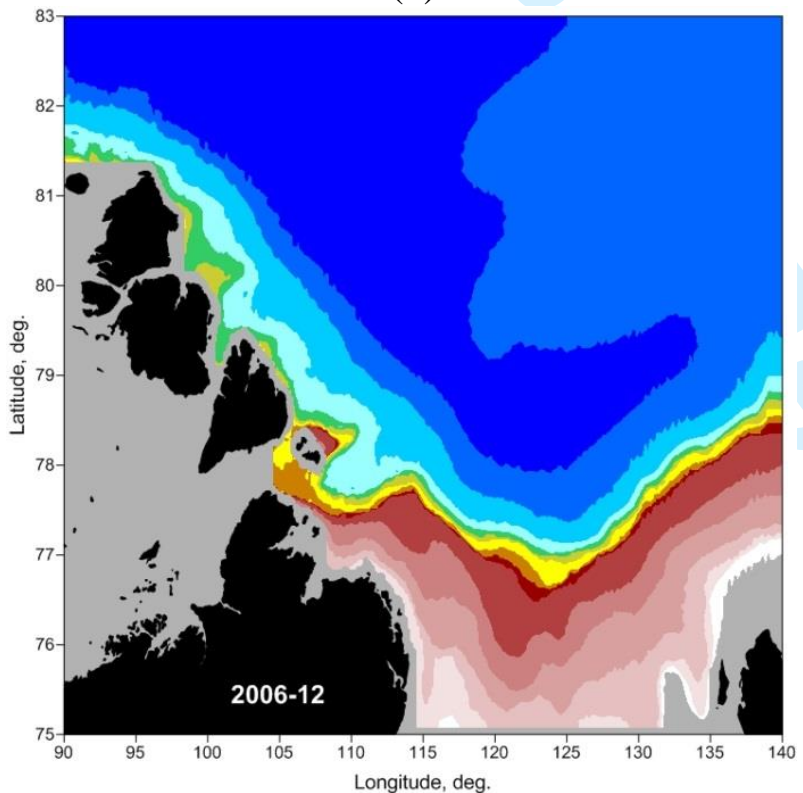

(c)

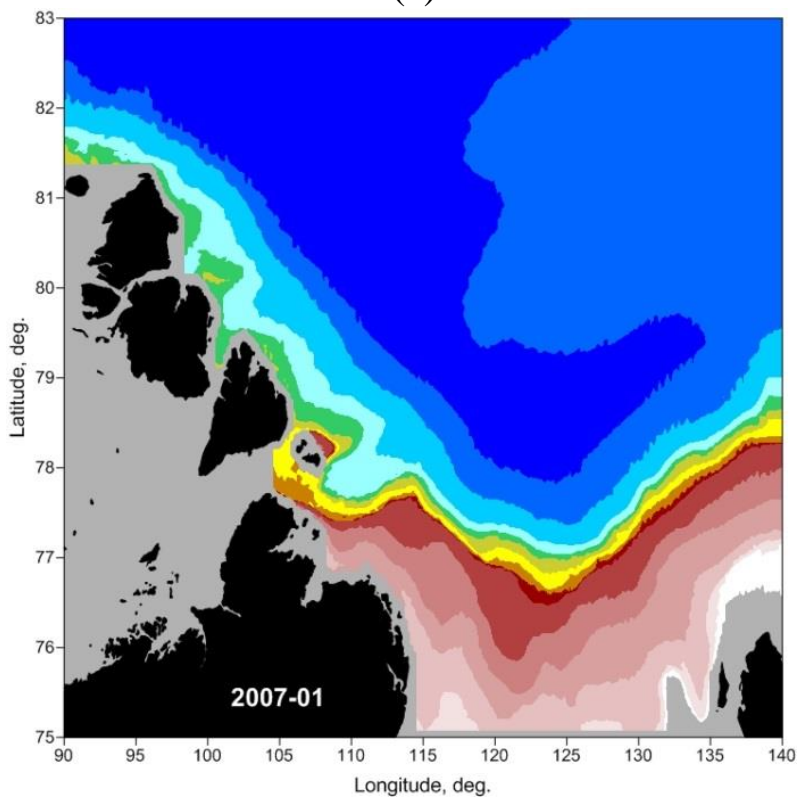

(i)

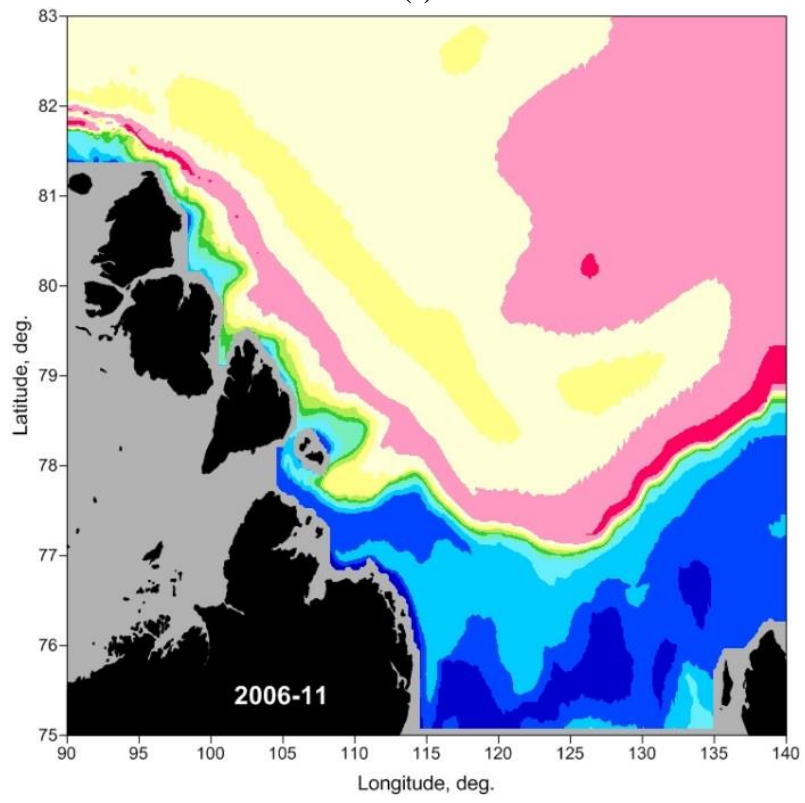

(j)

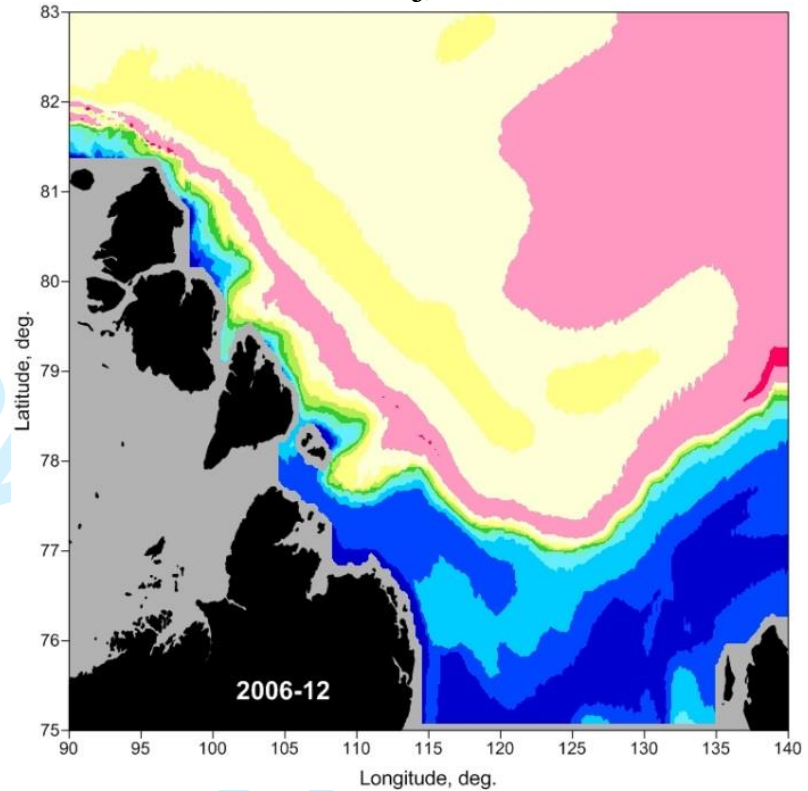

$(\mathrm{k})$

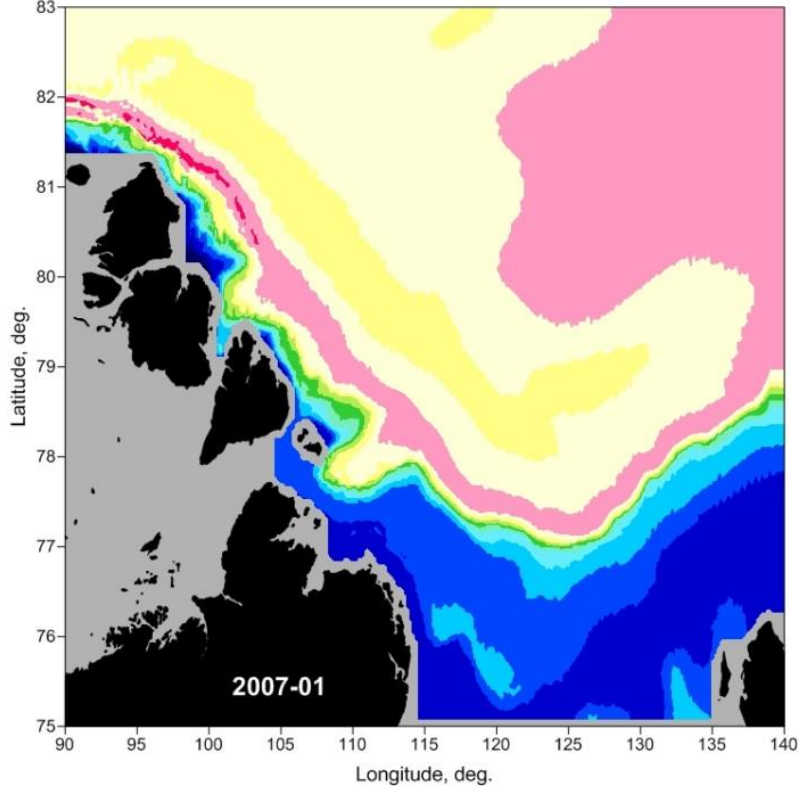


(d)

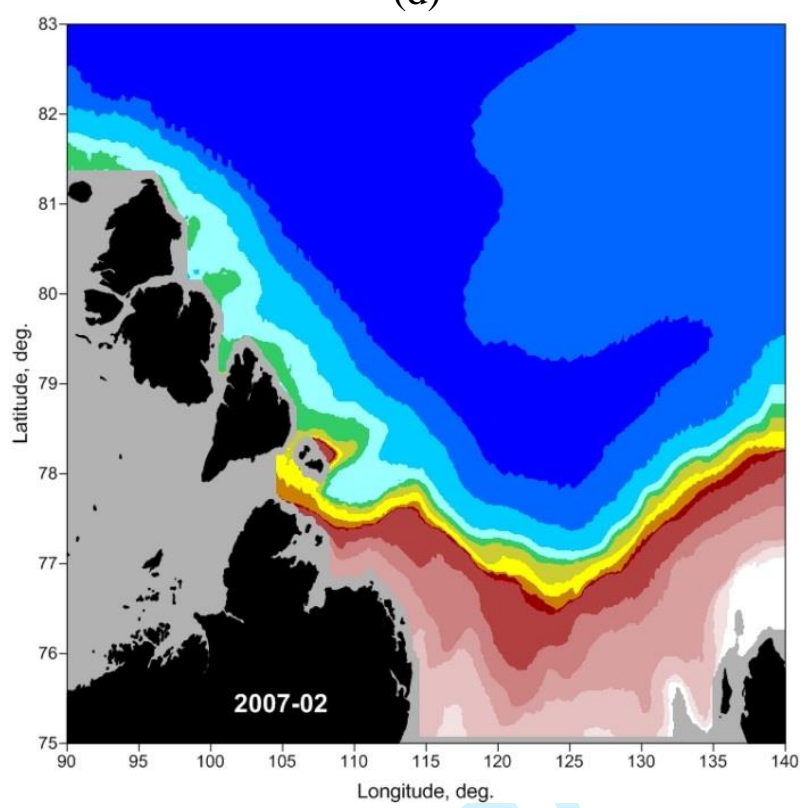

(e)

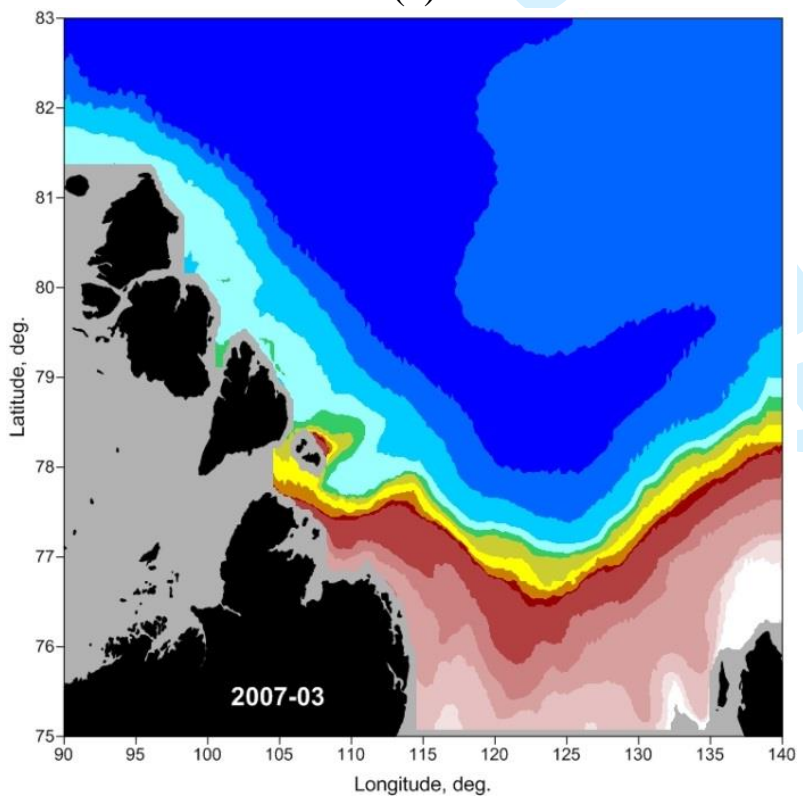

(f)

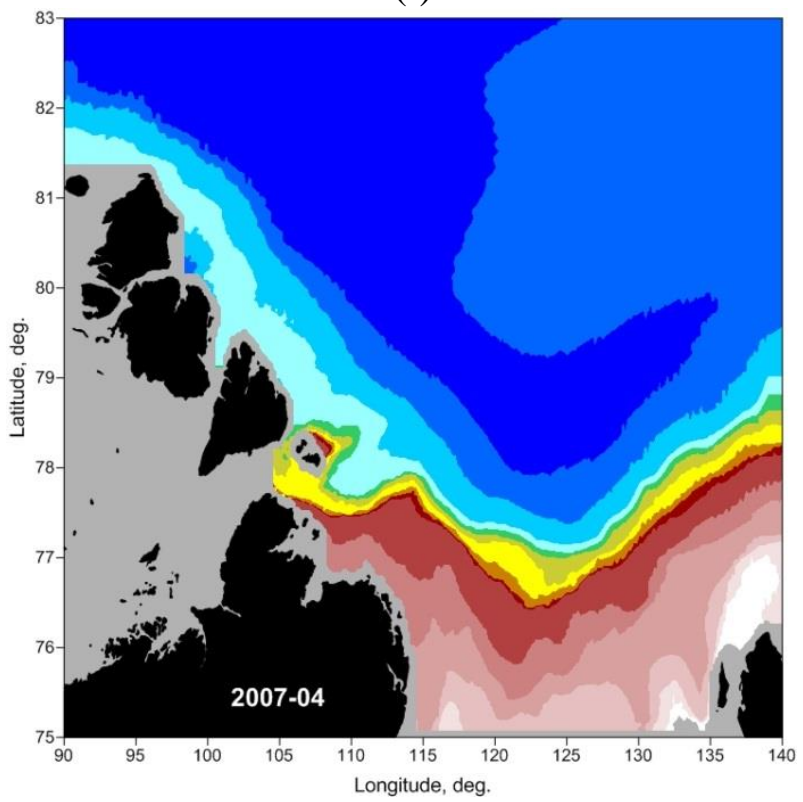

(1)

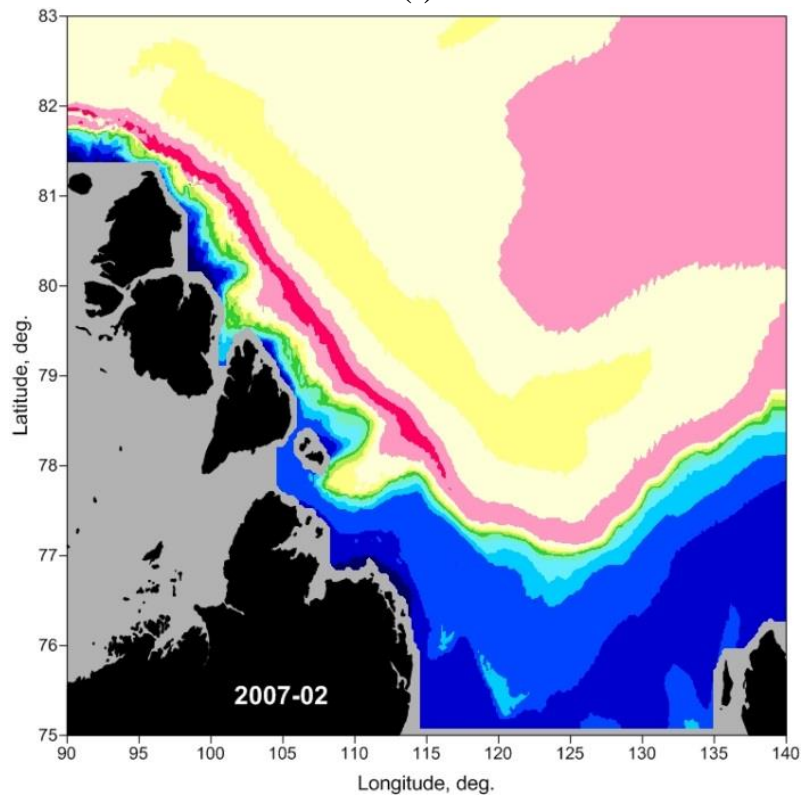

(m)

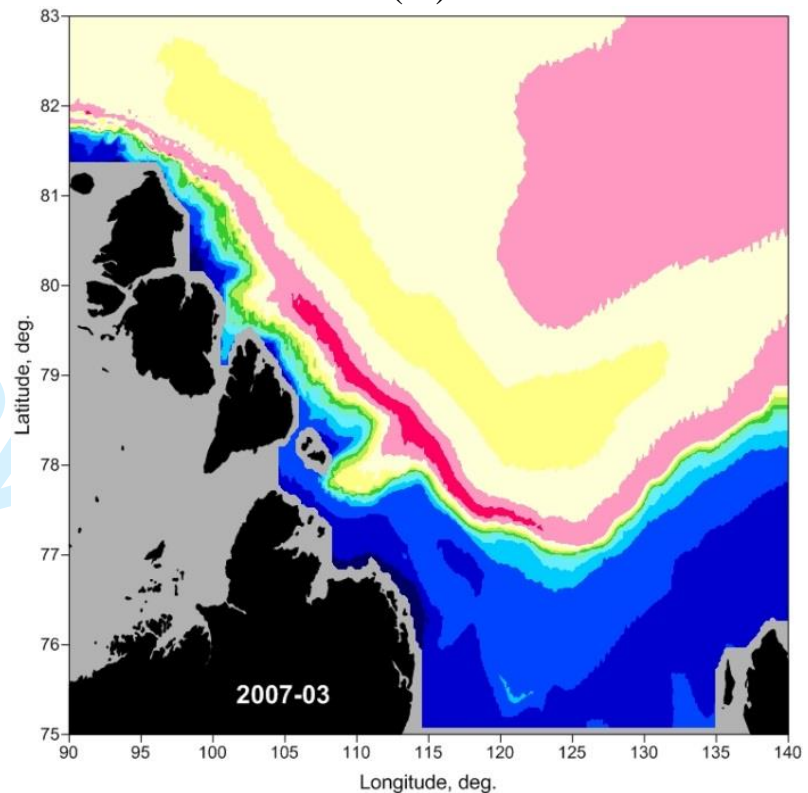

(n)

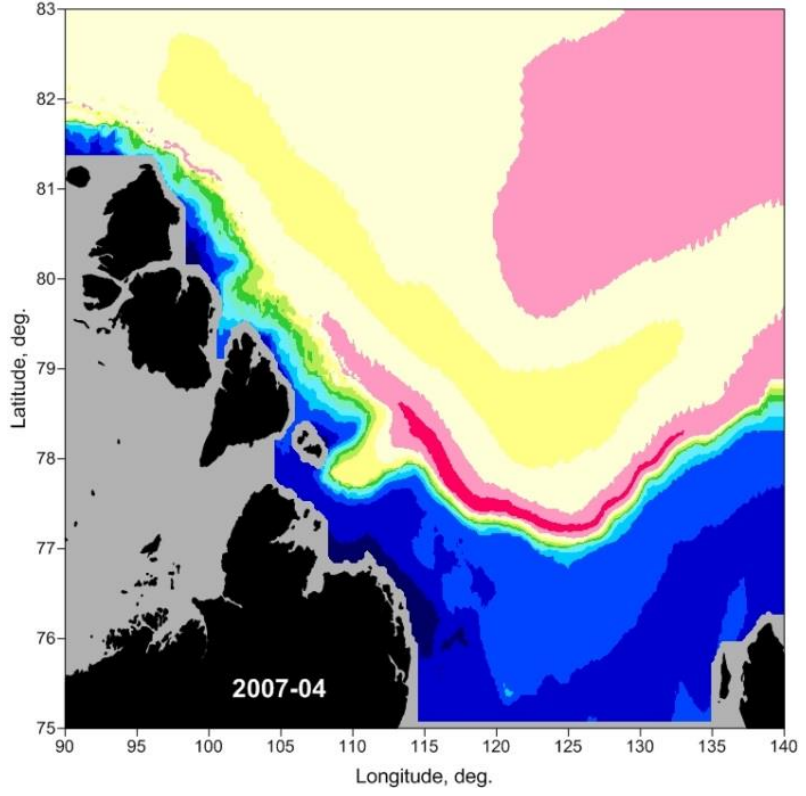


(g)

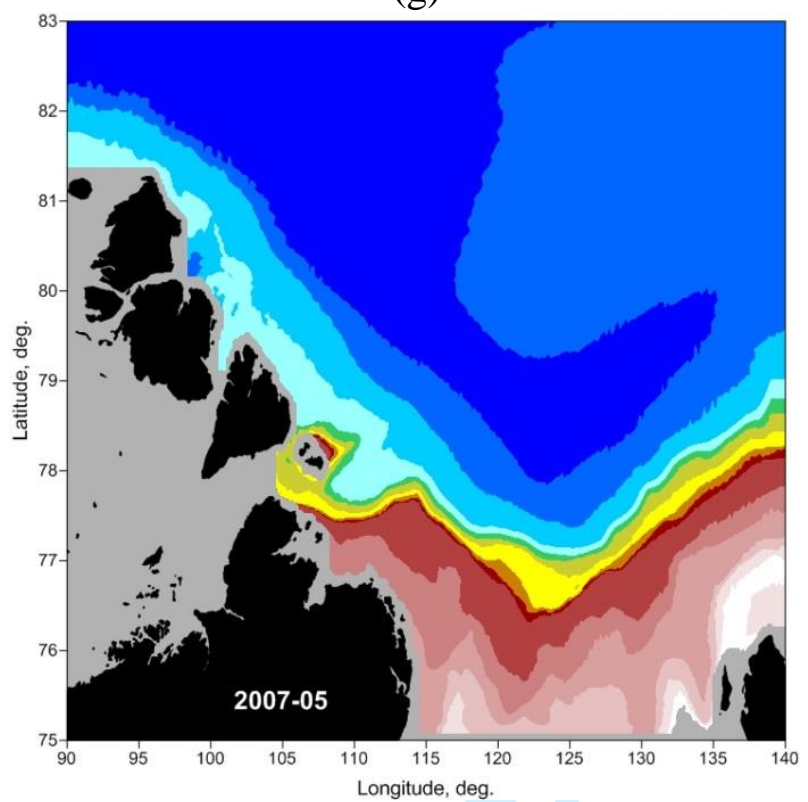

(h)
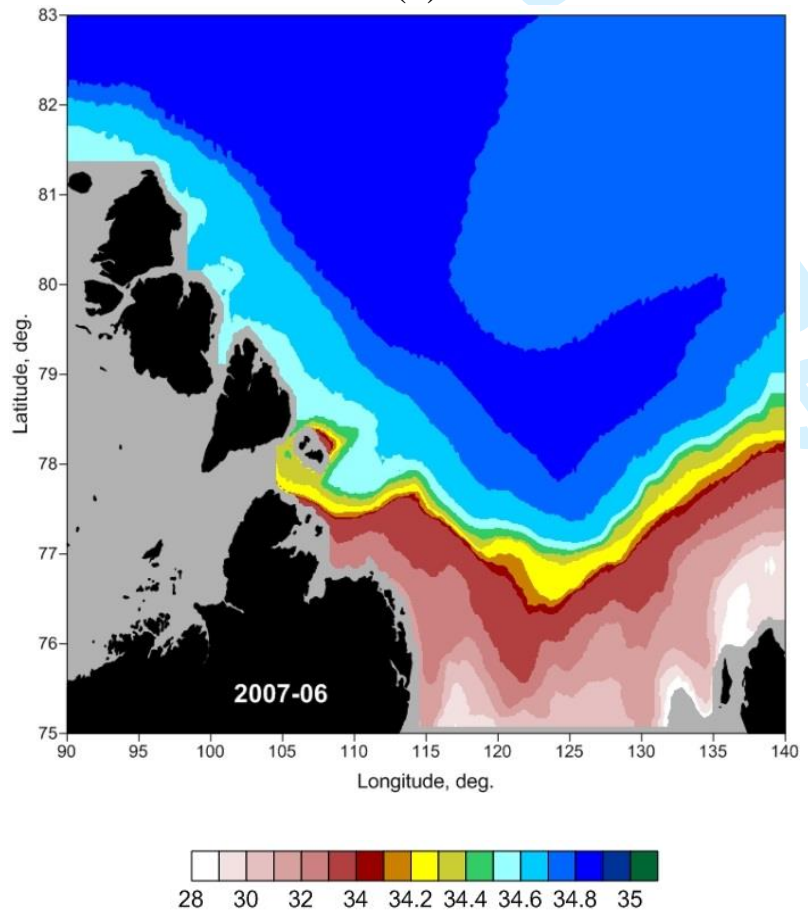

(o)

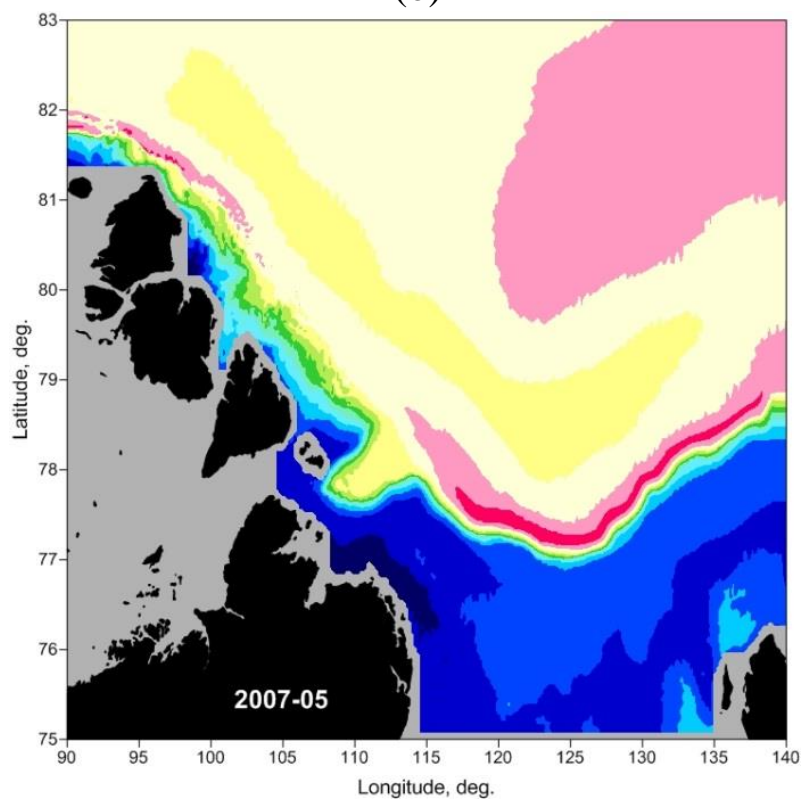

(p)

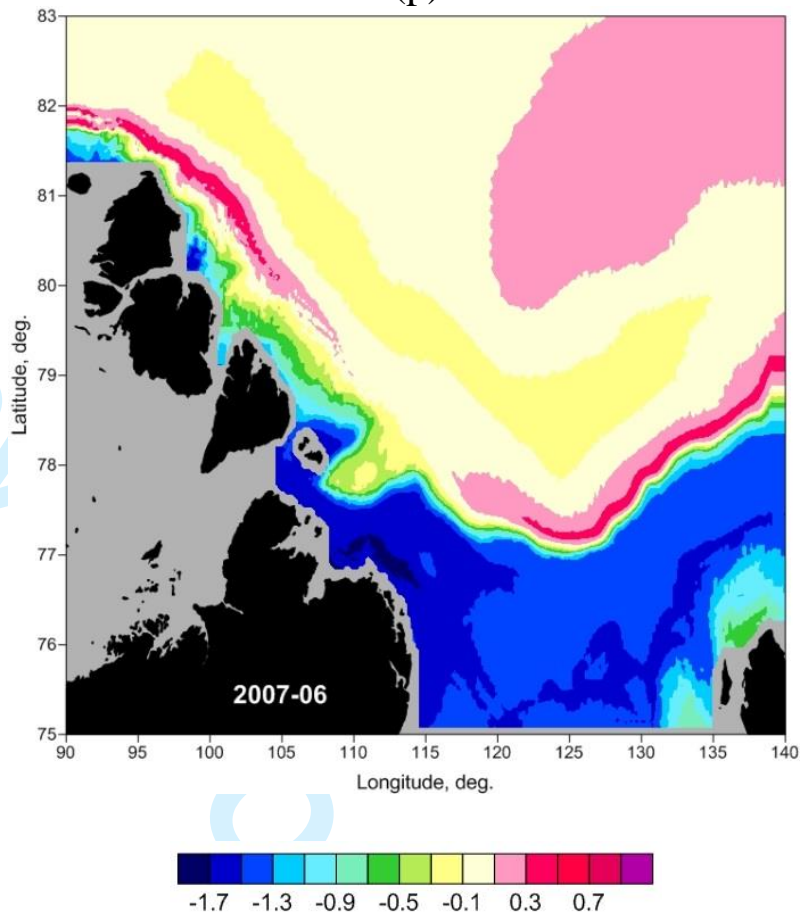

Figure S2. Evolution of average monthly salinity $(a-h)$ and temperature $(i-p)$ near the seabed (slevel 2) throughout the winter 2006-2007. 